\title{
A Twenty-Year Look at "Computational Geology," an Evolving, In- Discipline Course in Quantitative Literacy at the University of South Florida
}

Victor J. Ricchezza

University of South Florida, vricchezza@gsu.edu

H. L. Vacher

University of South Florida, vacher@usf.edu

Follow this and additional works at: https://digitalcommons.usf.edu/numeracy

Part of the Earth Sciences Commons, Higher Education Commons, and the Science and Mathematics Education Commons

\section{Recommended Citation}

Ricchezza, Victor J., and H. L. Vacher. "A Twenty-Year Look at "Computational Geology," an Evolving, InDiscipline Course in Quantitative Literacy at the University of South Florida." Numeracy 10, Iss. 1 (2017): Article 6. DOI: http://dx.doi.org/10.5038/1936-4660.10.1.6 


\title{
A Twenty-Year Look at "Computational Geology," an Evolving, In-Discipline Course in Quantitative Literacy at the University of South Florida
}

\begin{abstract}
Since 1996, the Geology (GLY) program at the USF has offered "Computational Geology" as part of its commitment to prepare undergraduate majors for the quantitative aspects of their field. The course focuses on geological-mathematical problem solving. Over its twenty years, the course has evolved from a GATC (geometry-algebra-trigonometry-calculus) in-discipline capstone to a quantitative literacy (QL) course taught within a natural science major. With the formation of the new School of Geosciences in 2013 , the merging departments re-examined their various curricular programs. An online survey of the Geology Alumni Society found that "express quantitative evidence in support of an argument" was more favorably viewed as a workplace skill ( $4^{\text {th }}$ out of 69$)$ than algebra $\left(51^{\text {st }}\right)$, trig $\left(55^{\text {th }}\right)$ and calculus 1 and 2 $\left(59^{\text {th }}\right.$ and $\left.60^{\text {th }}\right)$. In that context, we decided to find out from successful alumni, "What did you get out of Computational Geology?"

To that end, the first author carried out a formal, qualitative research study (narrative inquiry protocol), whereby he conducted, recorded, and transcribed semi-structured interviews of ten alumni selected from a list of 20 provided by the second author. In response to "Tell me what you remember from the course," multiple alumni volunteered nine items: Excel (10 out of 10), Excel modules (8), Polya problem solving (5), "important" (4), unit conversions (4), back-of-the-envelope calculations (4), gender equality (3). In response to "Is there anything from the course that you used professionally or personally since graduating?" multiple alumni volunteered seven items: Excel (9 out of 10), QL/thinking (6), unit conversions (5), statistics (5), Excel modules (3), their notes (2). Outcome analysis from the open-ended comments arising from structured questions led to the identification of alumni takeaways in terms of elements of three values: (1) understanding and knowledge (facts such as conversion factors, and concepts such as proportions and log scales); (2) abilities and skills (communication, Excel, unit conversions); and (3) traits and dispositions (problem solving, confidence, and QL itself). The overriding conclusion of this case study is that QL education can have a place in geoscience education where the so-called context of the QL is interesting because it is in the students' home major, and that such a course can be tailored to any level of program prerequisites.
\end{abstract}

\section{Keywords}

Quantitative literacy, STEM, geocscience education, Polya heuristic, spreadsheets in education

\section{Creative Commons License}

\section{(7) (8)}

This work is licensed under a Creative Commons Attribution-Noncommercial 4.0 License

\section{Cover Page Footnote}

Vic Ricchezza and Len Vacher are a doctoral student/teaching assistant and professor, respectively, in the Geology program in the School of Geosciences at the University of South Florida, Tampa. 


\section{Introduction}

The path by which Quantitative Literacy ${ }^{1}$ became a widely held learning goal for mathematics education in U.S. colleges and universities (e.g., Rhodes 2010) is associated with the names of some pioneer educators in the Mathematics Association of America (MAA) around the turn of the $21^{\text {st }}$ century. Foremost among these individuals are Linda Sons for the massive report of the MAA Subcommittee on Quantitative Literacy Requirements (the "Sons report," Sons et al. 1997); Lynn Steen for Mathematics and Democracy (Steen 2001), a seminal collection of essays, which made the case for quantitative literacy; and Bernard L. Madison for "Quantitative Literacy: Everybody's Orphan," an editorial in an MAA Focus newsletter (Madison 2001). The latter, "Everybody’s Orphan,” sets the frame for this paper, for in it, Madison articulated an issue that is still unresolved. In our opinion, the case example we describe in this paper illustrates a grassroots (as opposed to an administrative top-down) approach that can help address it.

According to "Everybody's Orphan,” education in numeracy (QL) education was suffering because no one claimed responsibility for it in our disciplinefocused curricula of the time. The mathematical content of QL rests on mathematics covered in the mathematics curriculum with the effect that, in practice, QL and mathematical literacy (ML) were considered the same thing by many non-mathematicians. So, of course, QL belonged in the mathematics curriculum; never mind that mathematics departments were already serving the many needs of the many mathematics prerequisites of many client departments. On the other hand, QL is richly "contextual," while students in mathematics "are asked to rise above context” while they learn mathematics (Madison 2001, 10). Moreover, as simultaneously laid out by Devlin (2000) in his "The Four Faces of Mathematics,” QL is a fundamental life skill in today's society, on par with literacy. It is the responsibility of every teacher. It sends the wrong message to our students if we regard basic quantitative skills as different from basic language skills. "Confusing quantitative literacy with mathematics simply confounds the problem” (Devlin 2000, 24).

Meanwhile, our discipline-geology, one of the mathematics departments' smaller client departments-was grappling with mathematics in context, as QL has come to be known, from the context side of the trope. For example, in

${ }^{1}$ QL, also known as quantitative reasoning [QR] and numeracy; see Vacher (2014), Roohr et al. (2014), Karaali et al. (2016) for semantics. As discussed by Karaali et al. (2016), the semantic swamp also includes distinctions between mathematical literacy [ML] and QL (and QR and numeracy). 
September 2000, the Journal of Geoscience Education published a special theme issue titled "Building the Quantitative Skills of Students in Geoscience Courses" (Macdonald et al. 2000a, b). Most of the 22 papers in the special issue addressed the strategy of embedding some mathematics into geoscience courses, particularly at the introductory level. Only two of the papers concerned a standalone geology course in which mathematics was the number-one priority. One (Lutz and Srogi 2000), from West Chester University, told of a geology shadow course that students take concurrently with their required calculus course; the course objective was to provide context-based problems for the students to solve in order to reinforce and illuminate the mathematics being taught in the linked mathematics course. The other paper described a senior-level course explicitly devoted to geological-mathematical problem solving. From the abstract (Vacher 2000a, 478):

Computational Geology is a spreadsheet-intensive, geological-mathematical problemsolving course recently developed at the University of South Florida. Requested by nontraditional students and now a required part of the geology curriculum, the course finishes off the required calculus sequence and its prerequisites. It makes connections between the various strands of mathematics and between mathematics and geology. It aims to enhance mathematical literacy and computational skills and to improve the mathematical comfort level of our students. It also promotes a mathematical problemsolving disposition that is useful to students regardless of whether they remain in geology.

That Computational Geology course is the subject of the present paper. In essence, as pointed out by one of the reviewers, it is "Part 2 to that JGE article some 16 years ago." In particular, our paper illustrates how the course has evolved from a course in mathematics concepts in geology to a course in QL in geology, as the instructor (the second author, HLV) learned of and came to value QL as a learning goal. The paper features interviews of 10 selected alumni of the course conducted as part of a qualitative research study (Ricchezza 2016) by the teaching assistant of the past two years (VJR). As pointed out by another reviewer, the study does not constitute, nor does it aim to be, an evaluation: the ten interviewees had multiple biases; the course evolved over the time of the sample's exposure; the number of interviewees is small, and most of them had connections to the course and instructor beyond being a student. Rather, that reviewer continues, the paper provides a case study of a QL course outside the mathematics department, in fact, in a STEM (Science, Technology, Engineering, Math) discipline. The qualitative study, in the words of the first reviewer, provides information "regarding the lived experiences of the participants in it and of the perceived benefits that the course provided" to them. The following narrative, then, starts with background history and evolution of the course, reviews the data of the qualitative study (Ricchezza 2016), and ends with a "So What?” 


\section{Background on the Course}

Computational Geology (hereafter, CG) was first offered in Spring 1996 under a different name "Math Concepts in Geology." It was offered once per year, usually in the fall. As of Fall 2015, it is now being offered every semester. Annual enrollments have doubled from 10-20 in the beginning to 30-40 now, in keeping with the growth of the geology program. Beginning in Spring 2016, the spring versions are being taught by a different professor (Chuck Connor, a volcanologist; HLV is a hydrogeologist; QL crosses subdisciplines in geology).

\section{The Early Years}

Vacher (2000a, 478) described how the course came to be. The explanation makes it evident why the course aims to be conspicuously useful to the students:

The Tampa campus of the University of South Florida is an urban university in which older, nontraditional students make up a large proportion of the undergraduate cohort. Many of the geology students have come to university after finding that the lack of a college degree was a problem, and they want to be prepared to do well in their jobs after graduation. Several years ago, some of these older students recognized the incongruity of their mathematics comfort level with their expectations about the importance of mathematics. As one of them put it to me: 'We insist that our kids know their math. I am not comfortable that I know mine well enough to do anything with it.' She and a small group of other like-minded students persuaded the geology majors to petition for a course that would help them learn to use mathematics in geology. That was the start of Computational Geology....

The math-in-context nature of the course is apparent from the 1997 syllabus (Vacher 2000a, 478)

This is a problem-solving course. The purpose is to enhance computational skills and increase mathematical literacy.... If you are uncomfortable with math or if you find your eyes glazing over when you come to the mathematical parts of your geology textbooks, you need to take this course. Sooner or later you will need to understand quantitative material - or else ignore an increasingly important part of your chosen field. College is the time to do it - not when you are out being paid as a skilled professional by someone who assumes you are math-literate and know what you are doing. (Emphasis added)

The content of the course listed in the 1997 syllabus is in Table 1. As recounted in Vacher (2000a), for each of the first couple of years, the topics were determined in a conversation with the students during the first class session. Looking at that list of topics now in combination with the use of mathematical literacy and math-literate in the statement of purpose quoted in the previous excerpt, it is worth noting HLV did not know or appreciate either the term or the concept of quantitative literacy at the time. Since then, the content of Computational Geology at USF has co-evolved from an ML-in-geology course to 
a QL-in-geology course as its instructor evolved from a STEM-oriented, GATC ${ }^{2}$ path-to-calculus guy to a staunch advocate of QL/QR as inspired in general terms by Steen and Madison (see citation-Numeracy indexes in Vacher 2016 and Grawe and Vacher 2017 respectively) and defined more specifically for the QL needs of students like ours by Gaze (2014).

Table 1.

Content of Original Computational Geology Course. From the 1997 syllabus (Vacher 2000a)

\begin{tabular}{cl}
\hline Part & \multicolumn{1}{c}{ Topics } \\
\hline I & Problem solving, computational strategies. Significant figures. Dimensions, unit conversions. \\
II & $\begin{array}{l}\text { Functions, especially polynomial functions, } \exp (x), \ln (x), \log (x), \text { and } a x^{b} \text {. Taylor series. Error } \\
\text { propagation. }\end{array}$ \\
IIII & $\begin{array}{l}\text { Lines, triangles, vectors, simultaneous equations, determinants. } \\
\text { IV }\end{array}$ \\
$\begin{array}{l}\text { Integration as a sum. Finite differences and natural integration. Using integral tables. Concept of } \\
\text { differential equations. }\end{array}$ \\
V & Descriptive statistics. Concepts of random variable, probability, and probability density function. \\
\hline
\end{tabular}

At the same time that the content of the course co-evolved with the instructor's thinking of and about QL, the conduct of the course co-evolved with his progressing experience using spreadsheets to teach mathematics in context. At the same time, too, both the number of JGE papers that involved geologicalmathematical exercises, problems or projects was increasing (see Vacher 2000b for bibliography), and the JGE papers involving mathematics were increasingly using spreadsheets (see Fratesi and Vacher 2005 for bibliography).

For the Computational Geology course, the initial use of spreadsheets (circa 1997-1998), again, is described by Vacher (2000a):

The course is a lecture course. The lectures are about mathematics. Geology is used to motivate the mathematics. All the mathematics is used to solve problems via multiple spreadsheet exercises each week. Students work on these exercises outside of class, individually or in groups - whatever works for them. They hand in the spreadsheet for a grade and revise it if necessary - repeatedly if necessary - until the output, including intermediate steps, is correct.

Soon thereafter (circa 1999), those "lectures ... about mathematics" gave way to short, "just in time" explanations of mathematics inserted into a framework of spreadsheet problems addressing geological questions (Vacher 2000a, 480). The first such spreadsheet problem in the course was "How Large is a Ton of Rock?" (Fig. 1). For example, as described by Vacher (2005) in the cover page for the subsequently developed module in the $\mathrm{SERC}^{3}$ repository:

\footnotetext{
${ }^{2}$ Geometry, algebra, trigonometry, and calculus (see Gaze 2014 for nomenclature and discussion of how the GATC approach contrasts with the needs to develop QL and QR in all students).

${ }^{3}$ Science Education Resource Center at Carleton College. http://serc.carleton.edu/index.html
} 
(This problem) comes in the second week of the semester. It accompanies the first problem-solving session. The preceding session is a computer-lab session which introduces Excel. The Ton of Rocks problem-solving session happens in a lecture room equipped with computer and projector. I start the session by posing the question: "How large is a ton of rocks?" I introduce the class to the fact that the class sessions will consist of such questions, and that they will be dividing up into groups to consider how to solve those questions. We discuss strategies of working in groups, and they go after the ton of rocks question.

The students soon decide that they need to know what kind of rock they are thinking about. What kind of minerals are in it? And what do I mean by "how large" anyway? The calmer tables think I mean volume. The more demonstrative tables motion the dimensions (length, width, height) of volumes. So we discuss the first step of Polya's heuristic ${ }^{4}$ : understanding the problem and drawing a figure. With agreement as to what the problem is (and a decision to start with a monomineralic rock), they discuss amongst themselves strategies to come up with a calculated length. They successfully design a plan in time for me to show them the first spreadsheet ... and discuss it before the end of the 1-1/2 $\mathrm{hr}$ session. They leave the session to complete the (assignment), (polymineralic rocks), which has "gone live" on Blackboard during the class session....

(In the process), students calculate the volume and then edge length of a cube, and the diameter of a sphere, of a variety of rocks weighing a ton. As part of the problemsolving activity, students build a spreadsheet to do the calculation, figuring out the cell equations as they go. The activity focuses on density and examines how this physical property varies with the kind and percentage of the minerals composing the rock. The rocks are: ice; vein quartz; gabbro; granite; porous arkose. The central quantitative issue is the weighted average. Students also need to apply their knowledge of the volume of spheres and cubes, and of course they get practice with unit conversions. ${ }^{5}$

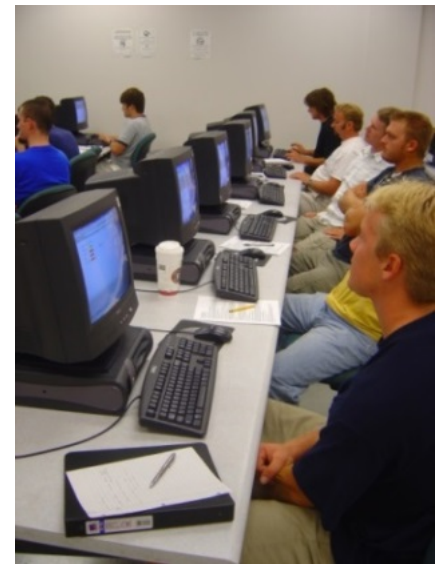

Figure 1. USF Geology students being introduced to their first SSAC module, How Large is a Ton of Rocks? Photo by Dorien McGee, Sept 2006. See Teaching with Spreadsheets across the Curriculum, http://serc.carleton.edu/sp/ssac/index.html

\footnotetext{
${ }^{4}$ Polya 1957
}

${ }^{5}$ Note that the central quantitative issue, weighted average, is a key tenet of QL, and certainly so are unit conversions (i.e., proportional reasoning). But, according to some, the use and particularly recall of geometric formulas for volumes would smack of ML. For us (from STEM), geometry (and algebra) in context belongs in QL just as much as arithmetic in context does. 


\section{Spreadsheet Modules}

The experience with spreadsheet-based assignments such as "How Large is a Ton of Rocks?” led to a sequence of NSF projects that, in aggregate, built a library of spreadsheet modules at SERC. The three projects were "Spreadsheet Exercises in Geological-Mathematical Problem Solving” (2002-2004), "Spreadsheets Across the Curriculum" (2005-2010) ${ }^{7}$ (Vacher and Lardner 2010), and "Geology of National Parks: Spreadsheets, Quantitative Literacy, and Natural Resources" (2009-2012) ${ }^{8}$ (Vacher et al. 2012).

The Spreadsheets Across the Curriculum (SSAC) library on SERC consists of four collections with nearly a hundred modules:

1. The General Collection: 55 across-the-curriculum modules, mostly from the 2005, 2006, and 2007 module-making workshops of the SSAC project. The modules, which range over 26 Library of Congress categories, were developed by 40 authors from 21 educational institutions in 11 states. Some of the modules from the 2002-2004 project were absorbed into this General Collection for wider dissemination.

2. The Geology of National Parks Collection: 26 modules made in collaboration with eight Research Learning Centers of the National Park Service as part of the 2009-2012 project.

3. The Physical Volcanology Collection: 9 modules developed by Chuck Connor (USF) and Peter LaFemina (Penn State) for their respective courses (2007).

4. The Geologic Hazards Collection: 9 modules developed by Tom Juster (USF) for his courses (2010-2011).

Each of the collections are cataloged with links enabling the collection to be searched by QL topic (Table 2).

As the SSAC library of spreadsheet modules was developed, they became a central focus of the Computational Geology course (McGee 2010). Table 3 lists the 14 modules used in the 2007 version of the course (25\% of grade). Their use is described in the following from the 2007 syllabus:

Much of the course will involve PowerPoint modules that elaborate on one or more geological-mathematical problems and how to solve them with spreadsheets. You will be asked to modify these spreadsheets in some way and hand in something to be graded. You will need to recreate the spreadsheets, including the cell equations. This work will take quite a bit of thought in some cases. You may work together on these assignments, but do note that the quizzes/exam will assume that you have the skills required to do the spreadsheets.

\footnotetext{
${ }^{6}$ http://nsf.gov/awardsearch/showAward?AWD_ID=0126500\&HistoricalAwards=false

7 http://nsf.gov/awardsearch/showAward?AWD_ID=0442629\&HistoricalAwards=false

${ }^{8}$ http://nsf.gov/awardsearch/showAward?AWD_ID=0442629\&HistoricalAwards=false
} 
Table 2

Counts of Spreadsheet Modules in SSAC Library by Quantitative Concepts, Excel Skills, and Subjects

\begin{tabular}{|c|c|c|c|c|}
\hline \multirow{2}{*}{ Breakdown } & \multicolumn{4}{|c|}{ Collection* } \\
\hline & GC & GNP & $\mathrm{PV}$ & $\mathrm{GH}$ \\
\hline \multicolumn{5}{|l|}{ Quantitative Concepts } \\
\hline Basic arithmetic; number sense & 51 & 24 & 9 & 9 \\
\hline Measurement; Data presentation and analysis; Probability & 45 & 19 & 9 & 4 \\
\hline Algebra; Modeling; Functions & 37 & 2 & 6 & 3 \\
\hline Geometry; Trigonometry & 11 & 5 & 5 & \\
\hline Calculus; Numerical methods & 11 & 1 & 2 & \\
\hline Creating and manipulating tabular data & 40 & & & 1 \\
\hline \multicolumn{5}{|l|}{ Excel Skills } \\
\hline Basic arithmetic & 51 & 20 & 9 & 8 \\
\hline Angles and trig functions & 5 & 2 & 4 & \\
\hline Other elementary math functions & 5 & 6 & 3 & 1 \\
\hline Statistical functions & 7 & 11 & & 2 \\
\hline Logic functions & 6 & 3 & & 2 \\
\hline Graphs and charts & 35 & 7 & 9 & 1 \\
\hline Other manipulations and functions & 10 & 3 & & \\
\hline \multicolumn{5}{|l|}{ Subjects (Context) } \\
\hline Mathematics, statistics and computers & 20 & & & \\
\hline Natural science & 28 & 26 & 9 & 9 \\
\hline Social science & 6 & & 2 & \\
\hline Library and information science & 1 & & & \\
\hline Humanities & 2 & & & \\
\hline Business, economics and finance & 10 & & 1 & \\
\hline Engineering, agriculture & 2 & & & \\
\hline Education & 3 & & & \\
\hline Health & 5 & & & \\
\hline
\end{tabular}

*Abbreviations: GC, General Collection; GNP, Geology of National Parks Collection; PV, Physical

Volcanology Collection; GH, Geologic Hazards Collection

That year (2007) was one of the handful in the 2000's that spreadsheet modules were so infused into the thinking of the course that the students made and presented a module as a team project (25\% of grade). From the syllabus:

By mid-October you will have seen and worked through several Spreadsheet Modules. The Team Project is for you to develop, present, and post one of your own. Teams will consist of $\sim 3$ students. Each team will develop and present a Spreadsheet Module. Every member of the team must participate in the presentation. There will be a team grade based on the quality of the module, the presentation, every team member's understanding of the geological-mathematical problems(s) and solutions(s), and the professionalism of the presentation and presenters. "Quality of the module" includes the content level of the geological-mathematical problem, the correctness of the solution, and the effectiveness of the module. "Effectiveness" will be judged by the following question: Would students benefit from working through the module? Individual grades will be the team grade times a weighting factor worked out from a matrix of teammate-generated distribution functions. 
Table 3.

Spreadsheet Modules Used in Computational Geology, 2007

\begin{tabular}{|c|c|c|c|}
\hline \multicolumn{2}{|c|}{ Module } & \multirow{2}{*}{$\begin{array}{l}\text { Authors, institutions* } \\
\text { Len Vacher (2005a), } \\
\text { USF }\end{array}$} & \multirow{2}{*}{$\begin{array}{l}\text { Quantitative Skill** } \\
\text { Weighted average. Also, unit conversions, ratio, } \\
\text { rearranging equations, volume, trial and error } \\
\text { strategy to solve inverse problem }\end{array}$} \\
\hline 1 & $\begin{array}{l}\text { How large is a ton of rock? - } \\
\text { Thinking about rock density }\end{array}$ & & \\
\hline 2 & $\begin{array}{l}\text { Is it hot in here? - } \\
\text { Spreadsheeting conversions in } \\
\text { the English and metric systems }\end{array}$ & $\begin{array}{l}\text { Cheryl Coolidge (2006), } \\
\text { Colby-Sawyer College }\end{array}$ & $\begin{array}{l}\text { Unit conversions. Also, scientific notation, ratios, } \\
\text { orders of magnitude; rearranging equations; XY } \\
\text { scatter plot, trend line; linear function }\end{array}$ \\
\hline 3 & $\begin{array}{l}\text { Earthquake magnitude: How } \\
\text { can we compare the sizes of } \\
\text { earthquakes? }\end{array}$ & $\begin{array}{l}\text { Laura Wetzel (2005), } \\
\text { Eckerd College }\end{array}$ & $\begin{array}{l}\text { Order of magnitude and logarithmic scales. } \\
\text { Also, scientific notation, ratios, rearranging } \\
\text { equations, linear and semilogarithmic graphs }\end{array}$ \\
\hline 4 & Calibrating a pipettor & $\begin{array}{l}\text { Bill Thomas (2005), } \\
\text { Colby-Sawyer College }\end{array}$ & $\begin{array}{l}\text { Variability and precision vs. accuracy. Also, } \\
\text { mean and standard deviation; relative and percent } \\
\text { error; bar and scatter graphs }\end{array}$ \\
\hline 5 & $\begin{array}{l}\text { Frequency of large earthquakes } \\
\text { - Introducing some elementary } \\
\text { statistical descriptors }\end{array}$ & $\begin{array}{l}\text { Len Vacher (2006a), } \\
\text { USF }\end{array}$ & $\begin{array}{l}\text { Exploratory statistical descriptors. Also, mean, } \\
\text { median, mode; variance, standard deviation; } \\
\text { percentiles, quartiles; interpolation; normal } \\
\text { distribution }\end{array}$ \\
\hline 6 & $\begin{array}{l}\text { Shaking ground - Linking } \\
\text { earthquake magnitude and } \\
\text { intensity }\end{array}$ & $\begin{array}{l}\text { Eric M. D. Baer (2006), } \\
\text { Highline Community } \\
\text { College }\end{array}$ & $\begin{array}{l}\text { Forward modeling. Also, logarithmic scales, unit } \\
\text { conversions, Roman numerals, exponential and } \\
\text { power functions, reading graphs, map scale }\end{array}$ \\
\hline 7 & $\begin{array}{l}\text { How large is the Great Pyramid } \\
\text { of Giza? - Would it make a } \\
\text { wall that would enclose } \\
\text { France? }\end{array}$ & $\begin{array}{l}\text { Len Vacher (2006b), } \\
\text { USF }\end{array}$ & $\begin{array}{l}\text { Estimation. Also, unit conversions, significant } \\
\text { figures, volume of a pyramid, ratio of volume to } \\
\text { cross-sectional area }\end{array}$ \\
\hline 8 & $\begin{array}{l}\text { From isotopes to } \\
\text { paleotemperature: Working } \\
\text { with a temperature equation }\end{array}$ & $\begin{array}{l}\text { Dorien McGee (2006), } \\
\text { USF }\end{array}$ & $\begin{array}{l}\text { Data analysis. Also, ratios, manipulating equation, } \\
\text { correlation, coefficient of determination, line and } \\
\text { column graphs, XY-scatter plot }\end{array}$ \\
\hline 9 & $\begin{array}{l}\text { Radioactive decay and popping } \\
\text { popcorn - Understanding the } \\
\text { rate law }\end{array}$ & $\begin{array}{l}\text { Christina Stringer } \\
\text { (2005), USF }\end{array}$ & $\begin{array}{l}\text { Exponential function. Also, geometric } \\
\text { progression, dimensions vs. units, rate of change, } \\
\text { logarithmic scale, trend line, Law of Large } \\
\text { Numbers. }\end{array}$ \\
\hline 10 & $\begin{array}{l}\text { Carbon sequestration in } \\
\text { campus trees }\end{array}$ & $\begin{array}{l}\text { Robert Cole (2006), The } \\
\text { Evergreen State College }\end{array}$ & $\begin{array}{l}\text { Power function. Also, order of magnitude and } \\
\text { scientific notation; allometry; exponential and } \\
\text { logarithmic expressions; percentage increase }\end{array}$ \\
\hline 11 & $\begin{array}{l}\text { Buffer capacity in chemical } \\
\text { equilibrium: How long can you } \\
\text { hyperventilate before severe } \\
\text { alkalosis sets in? }\end{array}$ & $\begin{array}{l}\text { Armando Herbelin } \\
\text { (2007), Lower } \\
\text { Columbia College }\end{array}$ & $\begin{array}{l}\text { Manipulating logarithmic equations. Also, } \\
\text { simultaneous equations, what-if modeling, } \\
\text { dimensional analysis, scientific notation, slope of } \\
\text { trend lines. }\end{array}$ \\
\hline 12 & $\begin{array}{l}\text { How far is yonder mountain? - } \\
\text { A trig problem }\end{array}$ & $\begin{array}{l}\text { Len Vacher (2005b), } \\
\text { USF }\end{array}$ & $\begin{array}{l}\text { Trigonometry, tangent. Also, effect of } \\
\text { measurement error; combining and rearranging } \\
\text { equations; finding solution by trial and error; circles } \\
\text { and radians }\end{array}$ \\
\hline 13 & $\begin{array}{l}\text { Earth's planetary density - } \\
\text { Constraining what we think of } \\
\text { the Earth's interior }\end{array}$ & $\begin{array}{l}\text { Len Vacher (2006c), } \\
\text { USF }\end{array}$ & $\begin{array}{l}\text { Weighted average. Also, unit conversions, volume } \\
\text { of spherical shell, inverse problem by trial and error, } \\
\text { concept of integral }\end{array}$ \\
\hline 14 & $\begin{array}{l}\text { Global climate: Estimating } \\
\text { how much sea level changes } \\
\text { when continental ice sheets } \\
\text { form }\end{array}$ & $\begin{array}{l}\text { Paul Butler (2006), The } \\
\text { Evergreen State College }\end{array}$ & $\begin{array}{l}\text { Estimation. Significant figures, manipulating } \\
\text { equations, area f circle, surface area of sphere. }\end{array}$ \\
\hline
\end{tabular}

* See References, Part B. ** Core and supportive quantitative concepts and skills identified by the author(s) on the first page of the published modules.

In addition to the spreadsheet modules, the class consisted of twice weekly lectures, an MAA textbook on QL (Anderson and Swanson 2005) for self-study, pre-lecture warm-up quizzes, and a comprehensive final. One week was open to 
allow for in-class team meetings, and two weeks were devoted to presentations and discussions of the team modules. Each team module was tapped for at least one question on the final exam.

\section{Currently}

The Fall 2016 edition of Computational Geology consists of Tuesday classroom and Thursday lab sessions. The focus of the course overall is interacting with word problems (inspired by reading Sweller et al. 2011). The Tuesday sessions are devoted specifically to ten problem sets consisting of more than 300 examtype problems developed over the years (Table 4). A problem set is made available on Tuesday for a week of try-on-your-own self- or group-study, and discussed, along with a worked-examples version the next Tuesday, following a warm-up, low-risk quiz (to encourage attendance and the week-long study).

Table 4.

Classroom Sessions for Computational Geology, 2016

\begin{tabular}{|c|c|c|}
\hline & Lecture/Problem Set & Description \\
\hline 1 & Introductory remarks & $\begin{array}{l}\text { Pre-test. QL vs. QR vs. Numeracy (vs GATC). Polya and problem } \\
\text { solving. Ten principles of QL according to Vacher }\end{array}$ \\
\hline 2 & PS 1. Numbers and Counting & $\begin{array}{l}\text { Concepts of arithmetic; traps of fractions; advanced counting (Venn } \\
\text { diagrams, inclusion-exclusion); binomial theorem and combinations }\end{array}$ \\
\hline 3 & PS 2. Quantities and Units & $\begin{array}{l}Q=n u \text {; simple unit coversions; unit conversions with multiple } \\
\text { dimensions; non-proportional unit conversions; reciprocal units. }\end{array}$ \\
\hline 4 & PS 3. Proportion and Percentages & $\begin{array}{l}\text { Meaning of proportional; meaning of proportion; meaning of } \\
\text { percentage; percent of what (Venn diagrams); percent of what (two- } \\
\text { way tables); percent of what (percent larger than); percent by what }\end{array}$ \\
\hline 5 & PS 4. Sums and Averages & $\begin{array}{l}\text { Notation and arithmetic; weighted and unweighted means; averages } \\
\text { of ratio quantities (arithmetic mean vs. harmonic mean); geometric } \\
\text { means; the integral as a sum }\end{array}$ \\
\hline 6 & PS 5. Ratios and Rates & $\begin{array}{l}\text { Geometric ratios; scaling; mixing ratios; rates; intensive vs. extensive } \\
\text { properties; Leibniz’s differential coefficient (derivative vs. } \\
\text { differential); geometric progressions and geometric growth }\end{array}$ \\
\hline 7 & PS 6. Estimation and Error & $\begin{array}{l}\text { Error propagation; one-significant figure estimates; finite differences } \\
\text { and numerical integration }\end{array}$ \\
\hline 8 & PS 7. Circles and Angles & $\begin{array}{l}\text { Circles and spheres; scaling (again); on a spherical Earth; angular } \\
\text { velocity; direction and distance; triangles and trigonometry; vectors; } \\
\text { curvature }\end{array}$ \\
\hline 9 & PS 8. Logs and Log Scales & $\begin{array}{l}\text { Manipulating exponents and logs; phi sizes and Richter Magnitude; } \\
\text { exponential decay; log scales; straight lines on graphs with log scales }\end{array}$ \\
\hline 10 & PS 9. Lines and Planes & $\begin{array}{l}\text { The sloping line; intersecting lines; the inclined plane; three point } \\
\text { problem }\end{array}$ \\
\hline 11 & PS 10. Modeling Functions & $\begin{array}{l}\text { Four straight-line, one-variable, two-parameter functions, } y= \\
f(x \mid a, b) \text {; power function; exponential decay; exponential growth; } \\
\text { log function; concept of differential equation }\end{array}$ \\
\hline 12 & Wrap Up & $\begin{array}{l}\text { Post-test. What numbers do you remember? What quantities do you } \\
\text { remember? }\end{array}$ \\
\hline
\end{tabular}

The Thursday sessions consist of six hands-on labs (e.g., Ricchezza and Vacher 2015, Vacher et al. 2016; see Fig. 2) and ten spreadsheet modules, nine of which are from the SSAC Geology of National Parks Collection (Table 5). Three 
of the modules are done in the computer lab, ${ }^{9}$ following self-study of two tutorial modules in the SSAC collection. The other six are done as homework assignments, which allow our course to co-exist with the many out-of-state field trips of concurrent discipline-focused geology courses.

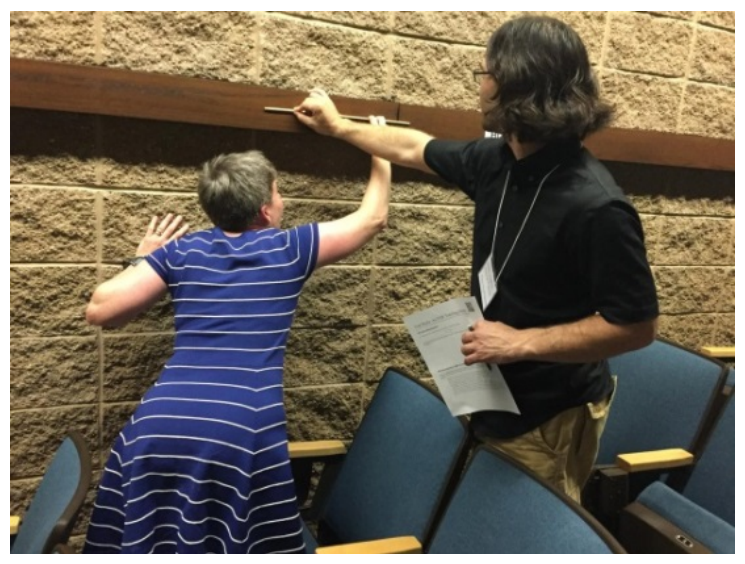

Figure 2. Workshop participants at the Earth Educators Rendezvous 2016 using a unit (chop)stick to measure a length to two decimal places during demonstration project by VJR (Vacher et al. 2016). This exercise is used in a CG lab session coordinated with the Problem Set on Estimation and Error. [Photo by Cailin Huyck Orr - CC-BY]

The lectures (problem sets) and labs are coordinated. The labs are $30 \%$ of the grade; the lecture material, which is assessed by three exams (the quizzes are a trace constituent), is $50 \%$ of the grade.

The remaining $20 \%$ of the grade involves writing assignments of two types. In the first assignment (10\% of grade), the students submit a total of four word problems (at 2-3 week intervals) to the course management system's discussion board for substantive (as opposed to frivolous “nice problem”) peer-discussion with an eye toward their potential use in future exams or problem sets. The purpose of this assignment is to have the students experience how difficult it is to write realistic and doable word problems that won't be misunderstood by somebody (i.e., QL, communication about quantitative material).

For the second assignment (10\% of the grade), students read The Math Instinct (Devlin 2005) and submit a series of private statements on the course management system. In the first week of class, they submit a statement "describing what you think of your experience with mathematics and your attitude toward the subject." Starting the second week of the semester, they submit a oneparagraph reaction to the successive chapters (there are 13) in the book each week. At the end of the term, they submit a two-page summary report of what they got out of the reading assignment. The purpose of this assignment is to have students experience a good read about math in a context that they likely would not have had thought about before. It also introduces them to another core component of QL, namely disposition and attitude.

\footnotetext{
${ }^{9}$ One of them was actually homework in 2016 because of shutdown due to Hurricane Hermine.
} 
Table 5

Lab Sessions for Computational Geology, 2016

\begin{tabular}{|c|c|c|}
\hline \multicolumn{2}{|c|}{$\begin{array}{l}\text { Hands-on Labs } \\
\text { Title }\end{array}$} & \multirow{2}{*}{$\begin{array}{l}\text { Description } \\
\text { Practice on arithmetic calculation without calculators, and on calculations } \\
\text { without pencil and paper. Prepare students to look back quickly on } \\
\text { problem solutions for quantitative plausibility (Polya heuristic, Part 4). }\end{array}$} \\
\hline & Arithmetic and mental math & \\
\hline 2. & Unit sticks on an ocean island & $\begin{array}{l}\text { Given only a single disposable chopstick use the stick as a basic unit of } \\
\text { distance and measure areas of nearby objects to at least } 3 \text { significant } \\
\text { figures using continued fractions (see Ricchezza and Vacher 2016). }\end{array}$ \\
\hline 3. & Mt. Everest vs. Mt. Kilimanjaro & $\begin{array}{l}\text { Students estimate the difference between the length of the Earth's radius to } \\
\text { the tops of Mounts Everest and Kilimanjaro, based on their altitudes. They } \\
\text { are then led through a multi-step estimation process to answer the same } \\
\text { question considering the Earth's oblate figure (see Vacher et al. 2016). }\end{array}$ \\
\hline 4. & Slide rules and log scales & $\begin{array}{l}\text { Students use 3D printed logarithmic slide rules to perform a variety of } \\
\text { basic arithmetic, logarithmic, and trigonometric calculations. They then } \\
\text { construct their own logarithmic slide rule to multiply and divide. }\end{array}$ \\
\hline 5. & Triangles in the wild & $\begin{array}{l}\text { Using clinometers in Brunton compasses, students measure angles to } \\
\text { stationary objects on campus, using trigonometry to calculate distances } \\
\text { that cannot be directly measured due to inaccessibility. }\end{array}$ \\
\hline 6. & Graph paper and straight line plots & $\begin{array}{l}\text { Students are provided with listed ordered }(x, y) \text { pairs to plot on arithmetic, } \\
\text { semi-log }(\log -x) \text {, semi-log }(\log -y) \text {, and log-log graph paper, to derive the } \\
\text { modeling functions that gives an apparent straight line for list. }\end{array}$ \\
\hline
\end{tabular}

\begin{tabular}{llll}
\hline \multicolumn{2}{l}{$\begin{array}{l}\text { Spreadsheet Modules } \\
\text { Title }\end{array}$} & Authors, institutions* & Quantitative Skill** \\
\hline 0. & $\begin{array}{l}\text { Spreadsheet warm up for SSAC } \\
\text { Geology of National Parks modules }\end{array}$ & $\begin{array}{l}\text { Dorien McGee, Meghan Lindsey } \\
\text { and Len Vacher, USF (2009) }\end{array}$ & $\begin{array}{l}\text { Concept of function. Also, order of } \\
\text { operations, order of magnitude, unit } \\
\text { conversions, proportion }\end{array}$ \\
$0 . \quad \begin{array}{l}\text { Spreadsheet warm up for SSAC } \\
\text { Geology of National Parks modules, } \\
\text { 2: Elementary manipulations ad }\end{array}$ & $\begin{array}{l}\text { Dorien McGee, Meghan Lindsay, } \\
\text { and Len Vacher, USF (2011) }\end{array}$ & $\begin{array}{l}\text { Visualization of data. Also, sorting } \\
\text { tabular data; bar, pie and line graphs; } \\
\text { XY-scatter plots }\end{array}$
\end{tabular}

1. A percentage stroll through Norris Geyser Basin, Yellowstone National Park

Tom Juster, USF (2010)

Percentage. Also, unit conversions, logarithms

2. How large is a ton of rocks?

3. How faithful is Old Faithful? Finding Tom Juster, USF (2011) order in random behavior

4. How much water is in Crater Lake? Using prisms to calculate volume

Heather Lehto, USF (2009)

See Table 3

Probability and frequency. Also, working with real data, histograms Estimation and accuracy. Also contour maps, volume, unit conversions

5. Nitrate Levels in the Rock Creek Park Watershed, Washington DC, 1: Measures of central tendency

Mark C. Rains and Len Vacher, USF, and Marian Norris, National Park Service (2011)

Len Vacher and Mark Rains, Average, mean, median, mode. Also, making and reading graphs; thresholds

6. Nitrate Levels in the Rock Creek Park Watershed, Washington DC, 2: Variability

7. Dunes, boxcars, and Ball jars: Mining the Great Lakes Shores

USF, and Marian Norris, National Park Service (2011)

Tiffany M. Roberts, USF (2010)

8. Deciviews from Look Rock, Great Smoky Mountains National Park: How hazy is it?

Len Vacher, USF; Jim Renfro and Susan Sachs, Great Smoky Mountains NP (2011)

9. Take a deep breath on the Appalachian Trail in Great Smoky Mountains National Park: How many Len Vacher, USF; Susan Sachs, Great Smoky Mountains NP (2011) Variance, standard deviation. Also, normal frequency distribution, outlier, percent difference Estimation. Also, volume, unit conversions, scientific notation, solid geometry

Algorithm. Also, scientific notation, logarithm, unit conversions

Ratio and proportion. Also, scientific notation, unit conversions, graph reading, orders of magnitude

* See References, Part B. ** Core and supportive quantitative concepts and skills identified by the author(s) on the first page of the published modules. 
Clearly from Tables 1-5, over the 20 years that the Computational Geology course has evolved, it has been transformed from a GATC bias to a QL course for groups of young scientists who will need to be able to solve challenging and consequential word problems involving quantitative material in their subsequent education and professional lives. This fact is emphasized in the first lecture (Introductory remarks), where the concept of a QL triad is discussed (Fig. 3), and students are given ten QL principles that will appear from time to time during the semester in commentary about the worked examples and during the lab sessions (Table 6).

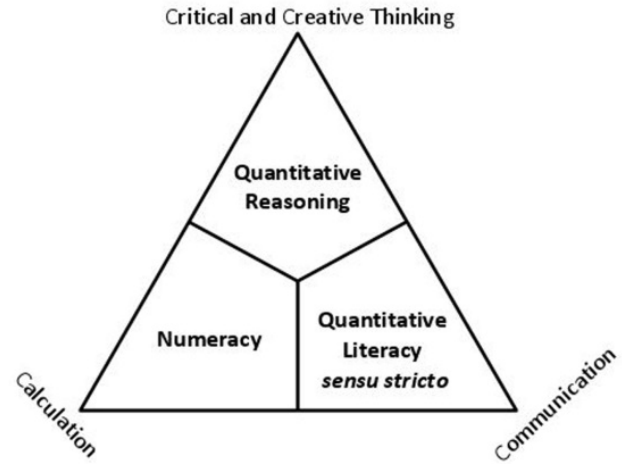

Figure 3. QL triad as presented in Computational Geology, 2016. The triad is Quantitative Literacy sensu lato. All three sectors in the triangle come into play during problem solving. Polya's four-step heuristic (Polya 1957) begins in the QL sensu stricto sector (communicating) with his "understanding the problem"; moves to his “designing the plan" in the QR sector (thinking); then to his "carrying out the plan" in the numeracy sector (calculating); then to his "looking back" in the QL sensu stricto sector (communicating the answer to the client using the correct number of significant figures and completely outlining the caveats and assumptions). (Vacher 2016, unpub.)

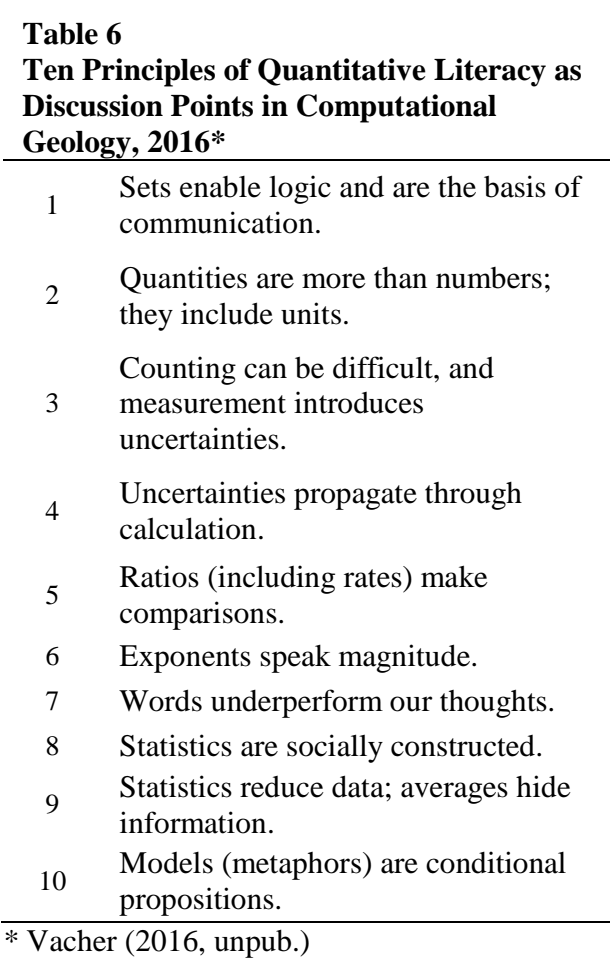

\section{Alumni Interviews}

\section{Motivation}

The Department of Geology merged with programs from the Departments of Geography, Environmental Science and Policy, and Planning to form a new School of Geosciences in Fall 2013. The merger generated the need to rethink all the undergraduate and graduate programs of the former administrative units. The 
largest changes occurred in the undergraduate geology (GLY) program, and, notably for this paper, some of those changes affected the "quantitative requirement” and Computational Geology specifically.

Before the revision, calculus 1 and 2 were required for both the BS and BA GLY degrees; there was no statistics requirement; and the BS students were required to take at least two "quantitative geology" courses from a list of four, one of which was Computational Geology (GLY 4866). ${ }^{10}$ With the 2016/2017 catalog, a course in elementary statistics has been added to both the BS and BA; calculus 1 is required for both degrees; the calculus 2 requirement for the BS was changed to calculus 2 or Computational Geology (to be renumbered to GLY 3866 in Spring 2017); and, for the BS, students can opt in for a named, transcriptrecognized geophysics concentration, which requires both calculus 2 and calculus 3.

To help define the "quantitative requirement" the GLY program's Undergraduate Curriculum Committee called upon the active alumni network (Rodriguez et al. 2002; Nocita et al. 2016) for input in the form of an online survey. The Likert-type survey listed 69 items under "How important are these skills and resources for geology students entering the workplace?” Averaging of the 23 responses produced the following ranking (emphasis added here):

1. Make oral presentations, ...

2. Expository writing.

3. Basic field mapping skills....

4. Express quantitative evidence in support of an argument....

5. Interpret potentiometric surface and water-table maps.

6. Use GPS and/or GIS and/or Remote Sensing instruments, ...

7. Utilize existing databases.

8. Explain information presented in mathematical models...

...

49. Interpret geologic history using existing data...

50. Physics (described).

51. Use algebra and equations to make a geologic calculation.

52. Biostratigraphy ...

$\ldots$

55. Use trigonometry to solve problems....

...

59. Engineering calculus 1 (described).

60. Engineering calculus 2 (described).

61. Determine probable genesis and sequence of rock and mineral assemblages.

...

68. Cellular processes, Biology 1

\footnotetext{
${ }^{10}$ The other three were Hydrogeology; Seismology; Physical Volcanology. Before the two-fromfour quantitative course requirement, Computational Geology was required of all majors (BS and BA) from 2000/2001 through 2009/2010. Before 2000, Computational Geology was not listed in the undergraduate catalog.
} 
69. Determine optical properties of rocks and minerals.

Although the feedback from the alumni had been sought to find out about the whole gamut of geology and supporting courses, and not the quantitative requirement in particular, faculty members interested in "quantitative geology" were especially intrigued by the response relative to the mathematics supporting courses. The discussions prompted questions including "What are students taking away from Computational Geology?” More precisely, "If the students are learning anything in that course, what is it?" In other words, the kind of questions that were being asked was the kind that frequently in our program is met with "Let's talk to our alumni network.” The timing was good for such conversations, too, because the course had been taught by the same individual since its inception, and for a variety of reasons, there was the potential for change in that regard. So, the time had come to ask, what has been learned from the Computational Geology experience, and what changes might be desirable? Further, because no one in our School of Geosciences is aware of any other geology course in the U.S. like Computational Geology in aiming explicitly at teaching quantitative literacy and geological-mathematical problem solving to geology majors, it was thought that diving more deeply into conversations with the alumni about the takeaways from the course would be of interest more broadly to both the QL community and the geoscience education community. In that context, we decided to investigate the matter by means of a qualitative study (Ricchezza 2016), as the first step along a $\mathrm{DBER}^{11}$ pathway to a broader investigation of teaching quantitative literacy within geoscience education.

Why start with a qualitative study? Quoting Feig (2011, 2), “Quantitative inquiry can tell a researcher what and how much of something happens, but the question of why is problematic." We were interested in what the alumni had to say.

\section{Methodology}

The interview protocol followed a narrative inquiry framework, which means it was intended to elicit the stories of the interviewees (Patton 2015). Questions were selected to be as open-ended as possible and still relate to the overall topic (the CG course and its impacts) in order to see what unexpected things would be said by those with different life experiences. As noted by Clandinin $(2006,44)$,

Narrative inquiry is an old practice that may feel new for a variety of reasons. It is a commonplace to note that human beings both live and tell stories about their living. These lived and told stores and talk about those stories are ways we create meaning in our lives as well as ways we enlist each other's help in building our lives and communities.

${ }^{11}$ Discipline-based education research. See http://serc.carleton.edu/NAGTWorkshops/DBER.html 
What does feel new is the emergence of narrative methodologies in social science research.

The following practical research questions drove the study:

1. What were the interviewed alumni's experiences in the course and what memories did they retain?

2. In what ways was the course of practical use to the interviewed alumni in their professional or personal lives, post-graduation?

3. What are the needs of the workforce, as expressed by the interviewed alumni, in regard to what could or should be taught in this course?

Selection of interviewees. Based on the three guiding research questions, HLV made a list of 20 alumni from which VJR recruited ten interviewees. Those persons all met the following criteria:

- Took and passed Computational Geology or Math Concepts as undergraduates between 1997 and 2013.

- Graduated from USF with a BS in geology.

- Were known by HLV to have gone on to professional success within their chosen career field.

- Collectively covered a spread of private sector/consulting, public sector/regulatory, and academic job roles in approximately equal measure.

Regarding the "professionally successful" criterion, it was not a rigorous or measured criterion in any way. Alumni who were deemed to meet this criterion simply met HLV's personal ideas for professional success as a "yes/no" proposition, and once that was determined, the matter was not considered further. Academics were not judged by whether they had achieved tenure, for example, or consultants were not judged by number or level of clients, or hourly billing rate, and regulators were not judged by caseload, administrative level, or other such criteria. Furthermore, any such consideration would vary according to time since graduation; someone who graduated in 1997 would be presumed to have accomplished a great deal more, professionally, than someone who graduated in 2013. Exclusion of any particular alumni was not intentional and was not a reflection of the ability or success of anyone excluded.

Additionally, the spread of career choices was not universal or random, nor did it cover all possible jobs within the three chosen "branches" of geological careers. As with the criterion of professional success, the inclusion of these interviewees as being sufficiently representative of the public/private/academic work sectors for geologists was not entirely rigorous, but was done for the purpose of seeing whether we could get some variation across the career branches of these accessible alumni. 
Interviewees. In accordance with the USF Institutional Review Board (IRB) approval (e22615), interviews with the ten study participants were conducted with informed consent. Participants were granted anonymity through the use of pseudonyms in the interview process, and, to avoid unnecessary bias, interviewees selected their own pseudonyms at the time of the interviews. Informed consent forms, complete transcripts, IRB approval information, and demographic information sheets are all on file with the interviewer.

Luke, Gilda, and Sam are currently employed as regulators at a regional governmental agency. Luke has completed an MS degree, and Gilda and Sam are in the process of doing the same.

John Doe, John Smith, and Medusa work as environmental consultants in the private sector for three different companies. John Doe and John Smith completed MS degrees. Medusa completed an MS degree and holds a state-level professional geologist license. Medusa also has past experience working as a regulator, and teaches introductory college courses part-time, and thus, although categorized by her primary occupation, could be considered under any of the career categories in this study.

Arya and Sunshine earned MS degrees and are currently completing $\mathrm{PhD}$ degrees while teaching. Jam earned an MS degree and is a permanent instructor at the collegiate level. Lee is working toward both her MS and PhD degrees.

Jam served as graduate teaching assistant (TA) for the CG course in graduate school. Arya unofficially served in this capacity as well, and wrote and organized a significant portion of the module and module accessory files. Sunshine was employed by HLV (mentioned in her interview) during summers of her MS studies organizing and improving the uniformity of the physical appearance of the modules and spreadsheets.

It should be noted that all but two of the interviewees (Medusa and Lee) did graduate work at USF.

Interviews. The study participants sat with VJR for a semi-structured interview. A semi-structured interview is one where a series of set questions is asked, and follow-up questions are allowed, based on the responses to the original questions. The interview protocol required that the following three questions be asked:

1. Please think back to when you took the computational geology course as an undergraduate at USF. Please tell me what you remember from that course.

2. What, from that course, have you used professionally or personally since graduating?

3. What would you like to see students in computational geology learning that would help them succeed professionally after graduation?

Follow-up questions were permitted and essentially open-ended, and they constituted the bulk of the interview time. Interviews were audio recorded, and participants filled out a demographic information sheet after recordings were 
completed. After interview recordings were transcribed and checked for errors, the audio recordings were erased, as voices are identifiable. Transcripts are available on request, but the interviewer reserves the right to redact identifying information before release.

Interviewees were not compensated for participation. Eight of the ten interviews were conducted in person. One participant was located out of state, and another had a work schedule that did not allow time to come to the USF campus. Both of these interviews were conducted via Skype video conference with audioonly recording. Interviewees who conducted their interviews via Skype sent signed copies of their consent forms via email and then orally answered the demographic questions, and the questionnaire was completed by VJR using the answers provided by the interviewees.

Participants were not provided information about the protocol before the interviews other than the name of the study (as "Alumni Narratives on Computational Geology") and an informed consent form indicating that an interview would take place. There were advantages and disadvantages to having interviewees enter the room without having seen the interview questions. On the positive side, interviewees could not rehearse answers. The responses they gave were presumed to represent their own responses and views, without time to change their minds or call a friend for assistance. On the other hand, lack of ability to prepare kept some interviewees (generally those who declared themselves to have poor memory) from having lengthy responses to questions, or remembering specific details. More than one respondent stated some variant of wishing they had a copy of their syllabus in front of them or that they knew what questions were coming beforehand.

The average of all interviews by length of recording was 36.7 minutes. The mean for the three regulators was 23.7 minutes, for the three consultants 33.9 minutes, and for the four academics 48.6 minutes. However, this simple mean reduces the data beyond any useful comparison. The range of time lengths for the interviews ran from 19:53 (Gilda) to 56:51 (Jam). Regulators ranged from 19:53 (Gilda) to 31:06 (Luke). Consultants ranged from 25:17 (John Doe) to 39:40 (Medusa). Academics ranged from 43:40 (Lee) to 56:51 (Jam). Academics did not overlap with either of the other groups' time ranges, and the overlap between consultants and regulators was small.

Transcripts. The interview transcripts were compared with each other for common words, phrases, and concepts using the constant comparative method (Glaser 1965). This method involves physically coding the responses where applicable, that is, highlighting words and phrases that show relevant data and then grouping similar responses where applicable to show trends in the data. This method also analyzes as the data are processed, and compares the various interview transcripts to each other throughout the process. The constant 
comparative method has become central to what is known as grounded theory analysis (Strauss and Corbin 1994) where codes are based on the data rather than pre-selected ideas from the interviewers or analysts chosen before analysis. The method of analysis is done in real time, as opposed to prior methods where judgment is suspended until all coding was complete. In reality, some combination of the two is the norm. One cannot sit in an interview room with a participant and hear them speak, listen to the interview recording, transcribe the interview word-for-word, correct the transcript for errors, and then code the transcript without having (at least informally) come to some degree of judgment about the meaning of the codes. Contrariwise, the viewing of fully coded transcripts as a whole gives some insights not apparent on the face of things during the initial stages of the interview and transcription processes.

\section{Results}

Ricchezza (2016) broke down each interview according to four topic areas: course evolution, course memories, uses of the course post-graduation, and suggestions for the course. Each of the latter three topic areas were further broken down into common suggestions (items mentioned by two or more interviewees) and unique statements (items either said by only one person, or stated in such a unique fashion as to be almost unrelated to the accounts of the other interviewees.)

Of particular interest to QL readers would be life skills and habits of mindwhat "serves many functions, including home, school, recreation, finance, work, testing, parenting, and citizenship" (Steen 1997) —and the evolution of the course itself. For the purposes of this article, therefore, we concentrate here largely on the instructional purposes and evolutionary changes through the life of the course and the uses that alumni made of what they learned in their professional and personal lives. To this end, course evolution, selected memories of the course, and later uses of the course are included. The findings in Ricchezza (2016) about suggestions for the course are not included.

Course evolution (1997-2014). Although it was not one of the research questions to explore how the mechanics of the course had changed over the years, discussions involving memories about a course would include the mechanics. Numerous points in that regard paint a picture of continual change. Following is an aggregation of memories of the mechanics in chronological order, closing with some memories from VJR when he observed the course in 2014 before becoming the graduate-student Teaching Assistant for it in 2015 and 2016.

Medusa (Spring 1997) described a course without a pre-set schedule of topics,

...he walked in and said 'what's holding you up? What sort of concepts are you having trouble with? What's not working for you? Why are you failing calculus?' And we spent the first couple of classes talking about that - what we felt we did and didn't understand, 
you know... things for which we didn't understand the relevance of why they were being presented to us. And he came up with a course description based on that. ${ }^{12}$

She described a course where spreadsheets-then not common in other departmental courses-were used to solve problems. The course involved a relatively large amount of calculus, as students had a lot of trouble with this subject in other courses.

Jam (Fall 2001) is the only student to describe the use of a textbook, Computational Engineering Geology (Derringh 1998), and she also described the use of Excel for problem solving. Homework for the course would consist of both Excel sheets and problems from the text. Class would start with a quiz, which was a homework problem with new numbers. After the quiz, a question or problem would be posed, and group discussion would ensue, which she found frustrating as she didn't know where to begin. Exams were on paper, but at times required students to explain what they would write in Excel to solve a problem, which Jam also found very frustrating without Excel in front of her to see. She started graduate school the next summer, and spent the summer helping HLV write what would become the first of the PowerPoint modules to accompany the spreadsheets and make them more accessible (see Vacher and Lardner 2005) before serving as TA for the course in 2002.

Sunshine (Fall 2006) described group discussion and paper-based tests. Modules were used as class assignments, as in all later iterations of the course. Sunshine later organized and improved the modules as a graduate student and wrote a new one. There was no textbook for the course, but a series of handouts, namely the "Computational Geology" series of 31 columns published in the Journal of Geoscience Education between 1998 and 2005 (Vacher 2005). Selected columns are still used in the course. ${ }^{13}$

Gilda (Fall 2008) described there being no TA for the course. She recalled modules and paper exams. Classes began with quizzes that introduced new material, but, “you don't really ever pass them," indicating a change from the homework review noted by Jam to more of a background assessment and challenge of misconceptions also observed by VJR in 2014.

Luke (Fall 2009) described module assignments and Excel-based exams. Arya (Fall 2009) also mentioned that the exams were done in Excel. She experienced a lecture-heavy format with the instructor one day per week and an Excel lab session with the TA on the other. She became an unofficial (voluntary undergraduate) TA for the course (Fall 2010), assisting the same TA she had

\footnotetext{
${ }^{12}$ This quote is left "unretouched" to show much of the style of transcription, complete with vocal tics and pauses. All further interview quotes have been "cleaned up" to facilitate easier reading.

${ }^{13}$ For the complete list of the Computational Geology columns with full text as published in the Journal of Geoscience Education between 1998 and 2005, see http://www.nagt.org/nagt/jge/columns/compgeo.html
} 
learned from the previous year. She noted that during that semester that the lecture sessions were different in format, with group discussions on solving a common problem. This format was more like what Jam experienced 10 years earlier. Arya noted that there was a campus-wide concern over a potential outbreak of H1N1 swine flu, leading to flexible attendance policies that semester. Lectures were therefore videotaped and posted, which was done only that semester.

John Smith (Fall 2011) described a tough "brain buster" question to start the class, which is consistent with Arya's account (2010). Exams were in Excel, but may have included portions on paper. Modules were heavily featured, and homework assignments were also in Excel. Sam (also Fall 2011) described Excelbased exams and module-based assignments, and the same class breakup of lecture once per week and a computer/Excel lab once per week with the TA.

John Doe (Fall 2012) said lecture days were generally occupied with a topic lecture the first half and a discussion the second half. Students were given a problem to solve for homework. Exams were mixed method (Excel and paper). Classes began with small quizzes to review material.

Lee (Fall 2013) was in the first class that was asked to write word problems from scratch, rather than simply solve them. Her assignments were moduledriven, and she did not mention the format of the exams. However, she correlated exams and Excel by saying, "I didn't really think of the labs too much when I was prepping for the exams.”

When VJR observed the course in 2014, it included paper exams and modulebased assignments. During that and the four preceding years, students would complete ungraded, Excel-based labs that were intended to help with the Excel and quantitative skills needed for the graded SSAC module(s) of the week. Beginning Fall 2015 with VJR as TA, the SSAC modules were reduced in number and replaced by more hands-on quantitative labs for about $2 / 3$ of the lab time, and all lab activities were counted for course credit. Word problems were used more prominently and also for credit. None of the changes since 2013 are directly relevant to the interviews and are included only to complement the interviewees' account of the evolution.

What interviewees remembered from the course, 1: Common themes. The exact question was, "Tell me what you remember from that course." Note the emphasis here on the use of the word from, as opposed to about-that is, substance, experiences, and affect, as opposed to mechanics (which is the gist of the preceding section). Eight items were mentioned by two or more interviewees in response to this question or in the follow-up questions to it (Table 7).

Luke called CG "probably one of the most important, for sure" of his courses, and Sam explained that the course was partially responsible for the choice of 
geology as a major. Jam said that specific events—discussed below—changed her life. Sunshine described herself as a "success story" from the course.

Table 7

What Interviewees Remembered: Common Themes*

\begin{tabular}{lcccccccc}
\hline & Important & Excel & Modules & $\begin{array}{c}\text { Unit } \\
\text { Conver- } \\
\text { sions }\end{array}$ & $\begin{array}{c}\text { Napkin, } \\
\text { Back-of- } \\
\text { envelope }\end{array}$ & $\begin{array}{c}\text { Difficult } \\
\text { Problem- } \\
\text { Solving }\end{array}$ & $\begin{array}{c}\text { Accessible/ } \\
\text { Gender } \\
\text { equality }\end{array}$ \\
\hline Medusa & $\times$ & $\times$ & & & & $\times$ & $\times$ & $\times$ \\
Jam & $\times$ & $\times$ & & $\times$ & $\times$ & $\times$ & $\times$ \\
Sunshine & $\times$ & $\times$ & $\times$ & $\times$ & $\times$ & & $\times$ \\
Gilda & & $\times$ & $\times$ & $\times$ & & & & \\
Luke & & $\times$ & $\times$ & $\times$ & & & \\
Arya & & $\times$ & $\times$ & & $\times$ & & \\
J. Smith & $\times$ & $\times$ & $\times$ & $\times$ & & & \\
Sam & & $\times$ & $\times$ & $\times$ & & & \\
J. Doe & & $\times$ & $\times$ & & $\times$ & & \\
Lee & & $\times$ & $\times$ & & $\times$ & & \\
\hline \multirow{2}{*}{ “Com } & & $\times$ & & & & \\
\hline
\end{tabular}

* “Common" means mentioned by two or more interviewees

Since the earliest iterations of the course, Excel spreadsheet calculations, and later, PowerPoint modules that guided them were used in class and in homework activities. All the interviewees mentioned the use of Excel in the course, with only Medusa-who took the course before the modules were introduced-not mentioning modules in some capacity. Jam took the course in the semester immediately before the introduction of modules but recounted her experience as a graduate student (and TA for the course) in helping to assemble and use the modules for the first time.

Almost all the interviewees - especially the regulators-mentioned unit conversions at some point in their interviews. Another common topic was quick estimation, also referred to as "napkin math" or "back of the envelope calculations." Sunshine stated that,

I remember doing math on a piece of napkin that was Dr. Vacher's goal for the class. That if you could sit in an airplane next to somebody and explain a math problem on a regular cocktail napkin, and you could draw a little diagram, that you were successful in his class.

Jam responded to the term "back of the envelope math" by saying, "yeah, I remember him using that phrase a lot." Arya said that they use "back of the envelope stuff all the time, just estimating, getting a good, quick figure.”

John Smith described the course as "extremely challenging. But informative, and in the end a very beneficial course for me." When asked to elaborate on how he found the course challenging, he said the following: 
[The course] was meant to force you to think things through thoroughly. Think deeply. He always said think deeply about things. And at first I kind of just thought well, I always think deeply, how can you not think deeply? I got to know what he meant by that. You really do have to dig, deep to come up with the correct approach. There was sort of a multi-step process to everything we did in there. You needed to first analyze the question on a face value level, take in the whole thing, and then you kind of broke it down, and then from there, you could kind of start formulating a way to attack it, a way to approach it, and that was, in many ways, the most important part of it, because if you started out the wrong way, you'll just end up going down a hallway and you'll never get out, you'll never get to the right answer.

This comment harkens to the four-step approach from How To Solve It (Polya 1957), which has featured heavily in the course throughout its time on campus. Polya's method of problem solving involved the basic steps of (1) understanding the problem, (2) designing a plan, (3) carrying out the plan, and (4) looking back. John Smith's quote here, although it doesn't mention Polya by name, seems a solid reference to the first two steps of Polya's plan.

Indeed, he was not the only person to refer to Polya, with others doing so by name. Jam said, "he was really big on Polya at that time," and then recounted steps one, two, and, emphatically, four, which she uses with her students today. Lee mentioned Polya and described the method as "it's so beautifully simple, and if you actually do it, it is incredibly helpful. If you actually do it. That was his entire course, was just learning how to think through things logically in a step-bystep manner."

Medusa, Jam, and Sunshine-the first three interviewees, chronologically, to take the course-all made mention of the course giving a sense of belonging, accessibility, and gender equality not present in other geoscience and/or STEM courses they took at the time. Sunshine told a tale of a history of personal math avoidance, and her choice with three other women to take steps to overcome this tendency toward avoidance (elaborated under “individual perspectives”). Jam stated that as a product of the time she grew up,

No one ever said to me you're a girl, you don't do math and science, but it was implied everywhere. My last science class was $8^{\text {th }}$ grade biology. And my last math class was $9^{\text {th }}$ grade business math where I learned to balance a checkbook. And so girls didn't do math and science. It's in my head. Sometimes I still shake my head why I'm a geologist, because I'm a girl.

Medusa said

....and it was no longer, you know, girls can't think in math terms versus boys it was let's go get to it, and when you can really do this, then I'll give you credence and we'll move forward, and that was his only criterion for the most part.

What interviewees remembered from the course, 2: Individual perspectives. This section refers to comments made by individuals that were not repeated by 
other interviewees, or which were so uniquely phrased as to place the response in its own category.

Lee-who took the course most recently among the intervieweesemphasized the real-world connections:

He was always really good in his exams about bringing applicable situations to when you would actually use this method or this particular topic, and so that was nice. It wasn't just, here's something, figure it out this way. It was asking you to actually go through things that you have learned in the course and decide what would be the best approach to figuring out the problem. And it was a real-world approach and that was, that was really nice.

John Smith compared requirements from the course that later became applicable to his career, in particular.

Up to that point I had no idea how to convert between a hectare and an acre, for example, and by the end of it I could do it in my sleep. There was all kinds of just great information embedded in it. That he just expected us to just know. I mean, it was our responsibility to learn that stuff and know it and have it locked down. Because at the end of the semester, when the exam comes around, he's not telling you what the diameter of the Earth is. He's not telling you the conversion factor between one thing and other. That's your responsibility to know that. And that's something that really carries through to the professional world. There's all kinds of stuff like that, that you just have to know. You can't always look in your book, you can't always Google something, you've got to know what you need to know to do the work, and that's something he taught me in that class, and something he really grilled into us, is learn these basic building blocks of things, because you should know them, there's no reason not to know them. So, in that sense, I took a lot from it with me, things that didn't seem important to me at the beginning, and then at the end there's all kinds of stuff like that.

\section{Sunshine described how she came to grips with the course.}

I became really good friends with some ladies in the course. So if anybody has met Vacher, he can seem very unapproachable at first, and not relatable. So there's four of us. We did not succumb to Dr. Vacher's intimidating aura, so we sat in the very front row. All four of us in the front row. Everybody else sat back behind us pretty far back. We wanted to learn. We wanted to hear what he had to say, and the only way to truly be successful in his course was to be involved and to be connected to Dr. Vacher, to be able to stop him whenever you have a question or be able to ask him to elaborate. So we sat in the front row and we asked him questions all the time... he was not used to that. And all four of us are still very good friends.

And, she added a story regarding an experience that improved her personal confidence.

I was always kind of a math avoider, and I remember we had this one problem about a meteor impact, and we were looking at the blast radius, so we were looking at trying to figure out how big the meteor that hit, based on the crater that it produced and then the ray around it. And I remember because I'm still proud of myself because I actually answered a question and I answered it correctly. He asked the students "OK, now, what are some of the measurements of the... the impact that we could use to figure out how 
big this meteor was?" And no one was saying anything. And I'm like, well, this seems pretty simple to me, so I raised my hand. And he was like "Sunshine". So I said "um, well, can't you just measure the length of the ejecta? And figure out how fast it was coming that way?” And his face, like, lit up when I said that. I was almost cause now that that I'm a professor I know what he felt, like, she got it, she gets it! You've got to critically think about something. How can you look at a problem and figure out the answer that you need to from the data that you're given? I remember that being a defining moment for me. And the rest of the class looked at me like, how did you get that?

Jam also told an extraordinary story relating to an experience in the course that shaped her future.

It was probably the first day of class. He taught about I don't even remember about what. But as I was leaving the room, I walked up to Dr. Vacher, and I said, "I just want you to know I don't do math.” And he looked at me, and he didn't respond as far as I can remember. And he just let that go. I was very proud of myself for saying that, because this is the course that nobody wanted to take. Everybody was afraid of him. A little while into the semester I could hardly wait to get home every day to do the homework. It was the first time in my life I was ever successful at doing any kind of a math problem, a word problem. The homework, Excel stuff. And about, I'll guess a month into the semester, he asked me if I remembered what I had said to him the first day. And I turned red and said "Yes, I absolutely remember that". And he said, "You know, [Jam], if you weren't able to read, you would have been so embarrassed about that that you would never have told me or anyone else. You should be just as embarrassed to have said you weren't quantitatively literate.” And that statement changed my life.

When asked, on follow-up, about how this experience changed her life, she explained that it made her want to be quantitatively literate. Jam further described that this goal led to a persistence, saying

I would struggle with the homework, but I would sit there and do it until I understood what I was doing. I would do the math problems and be in awe of myself when I got an answer in the back of the book that matched.

Jam later discussed how she learned more, conceptually, about what calculus and other forms of math really meant and why they were used, in just a few minutes in the course than she had in entire semesters of standard math courses.

Somebody says the word logarithm and I say, yeah, man, he made it so clear. And I've said this to him, I've said it to current and former students in his class, and I've said it to people outside of USF. I really felt like I learned more in a ten minute discussion in his class about calculus than I learned in two semester sitting in calculus math class here at USF. At the end of those two semesters [of engineering calculus 1 and 2], I didn't know why you do calculus. I never got that a derivative was the slope of a line and that the integral was the area under the slope. Two semesters, I never got that. I learned how to take letters and numbers here, and then there was the equal sign, and I had learned how to change those same letters and numbers and make them different over here. And I could do it. I think I got an A or A- in calculus, which I was like, how did I do that? I didn't understand it at the end. And in ten minutes, when he explained this is what a derivative is, all it is is the slope of a line, oh, the light came on. And... you don't hear that in a 
math class. At least if you do, I wasn't paying attention that day. If they ever said a derivative is the slope of a line? I completely missed that.

Medusa-whose early iteration of the course involved a relatively large amount of calculus compared to later sections-described something similar regarding geology, math tools, calculus, and confidence.

The course allowed me to see mathematics as a tool that I can realistically use in the applications of geoscience instead of viewing calculus etc. as a separate thing from geology. And it took the fear away. It was a very common theme at the time that folks felt challenged by a lot of the math courses that they were in. They were having trouble with them. Some of them were even failing them. When these concepts really are quite central to geology. And Len saw them as central, didn't understand why we weren't functioning within both equally well, so he looked at how those courses are being taught, and how geologists think, and created a course that took the fear out of math, which is huge.

When asked how this was accomplished, she responded as follows:

Well, he answered what I call the primary questions. Which actually may be a concept I got from Len, I don't remember where I got it; it very well could have been Len. Primary questions being "so what?" and "who cares?" So he went back to relating to the concepts that geologists work with every day. You know, a derivative is change over time, that's all it is. Geology is change over time. Almost everything we look at in geology is change over time. Until he said that to me, in that sentence, I had never seen it, I had not seen a derivative that way, and I had not really applied, oh, that's why I might want to use that in geology. Why the mathematics and the computations are so inherent in the application of geoscience. He firstly made it relevant for us, and secondly, was able to get to the nuts and bolts of how you use it instead of just fluttering about with the theory that a lot of the courses were doing. This is more physics than calculus, but a ball's coming at you at a certain angle, and if somebody hits the ball, how's it going to go? Well, you know, in my mind, the answer to that was 'home run'. The nitty gritty of that didn't matter to me, and Len was able to help me understand exactly why I would want to know that. And why I would want to use these tools to get there. So he made it a tool that I can use, and made it something I wasn't afraid to use, and made it something I was excited to use and felt empowered by instead of somewhat fearful of.

What interviewees mentioned was useful from the course, 1: Common themes. The exact question was, "Is there anything from the course that you used professionally or personally since graduating? Seven items were mentioned by two or more interviewees in response to this question or in the follow-up questions to it (Table 8).

Several alumni, speaking in a general way, stated that they use the material or learnings from the course on a daily basis. Lee, when asked this question, said, "every day... every single day." She later elaborated by saying,

I use Excel. I use computations every single day, and it was really eye-opening to get to grad school and to see it, the focus was way more on computation than I ever gathered when I was at USF. 
John Smith responded to the question by saying,

definitely the Excel work. For sure. Every day of my life I live and die in Excel at my job.

\begin{tabular}{|c|c|c|c|c|c|c|c|}
\hline \multicolumn{8}{|c|}{ What Interviewees Mentioned as Useful: Common Themes* } \\
\hline & Excel & $\begin{array}{l}\text { Their } \\
\text { notes }\end{array}$ & Modules & $\begin{array}{l}\text { Weighted } \\
\text { Averages }\end{array}$ & $\begin{array}{c}\text { QL/ } \\
\text { Thinking }\end{array}$ & $\begin{array}{c}\text { Unit } \\
\text { Conver- } \\
\text { sions } \\
\end{array}$ & Statistics \\
\hline Medusa & $x$ & & & & $x$ & & $x$ \\
\hline Jam & $x$ & & $x$ & & $x$ & & \\
\hline Sunshine & $x$ & & $x$ & & & $x$ & \\
\hline Gilda & $x$ & & & & $x$ & $x$ & \\
\hline Luke & $x$ & & & & $x$ & $x$ & \\
\hline Arya & & $x$ & $x$ & $\times$ & & & $x$ \\
\hline J. Smith & $x$ & & & $x$ & $x$ & & $x$ \\
\hline Sam & $x$ & & & $x$ & & $x$ & \\
\hline J. Doe & $x$ & & & & $x$ & $x$ & $x$ \\
\hline Lee & $x$ & $x$ & & & & & $x$ \\
\hline
\end{tabular}

The specific statement that Excel/spreadsheet work was commonly used was universal, one way or another. In fact, only Arya did not specifically mention using Excel, although she later said graduate students need to know how to use it well (and we know independently that she uses it in her dissertation research all the time). John Smith, one of the consultants, went on to say,

I'll write my reports with pen and paper if you want me to, but if you take Excel away from me, I'm dead.

Luke, one of the regulators, referred to reviewing the Excel sheets submitted for permits, and the knowledge for the course helping him to understand what he sees:

I learned a lot about Excel; I can look through a sheet and reverse engineer it, find out the calculations, things like that, that people have submitted to me.

John Doe mentioned Excel for both professional and personal purposes, saying,

I'm always pulling up Excel, and doing some statistics on financials or stocks, or anything that I'm interested in.

Sam said,

Yes, I definitely use Excel in my personal life for maintaining finances. 
Both Arya and Lee mentioned that they still have all their notes and labs from the course and refer back to them frequently. Referring to both the computational geology course and a somewhat similar graduate-level QL-in-geology course titled Math Concepts for Professional Geologists, Arya said,

I still have all my notes from both those classes and I actually still refer back to them. .I've used my notes for other classes just to look at like vector algebra or something like that, that's sometimes I don't memorize those things, I have to go back and review.

Lee, another PhD student, expressed it similarly, saying,

I actually still have all the labs and all our lab exercises just in case I forget exactly how to do one thing.

Sunshine and Arya mentioned using the modules in teaching, and Jam mentioned the use of Excel and the tutorial modules in her teaching as well. As a graduate student working with both HLV and the course TA at the time, Sunshine remembered,

We actually created pre-modules to the modules, to help students that go, ok, this is what a module is about, this is what Excel is about, these are the equations that you could be using in Excel. So kind of a, let's get the students up, all on the same playing field, before we just throw this complicated module at them and possibly they don't even understand the quantitativeness (sic).

These "pre-modules" she mentions here are tutorial modules that are still used in the CG course and in several other courses as preliminaries for the Excel work within the courses.

Two interviewees mentioned using averages frequently. Arya has a history of study and teaching in sedimentary geology, which includes the topic of grain size distribution in sediments. She discussed the need to use (and teach) weighted averages to determine the mean grain size of sediments. John Smith said,

Well, we'll go to averages. There's different kinds of averages, and they do different things for different reasons, you know? There's a right time to use an, um, arithmetic mean. There's a right time to use a geometric mean.

Several interviewees referred to using QL specifically, or to the skills under its umbrella without using the actual QL label. For example, Luke said that the course

... made me think about (the math I already knew) a little bit differently.

More explicitly, John Smith stated,

Quantitative literacy is one of those... it's a life skill. Once you learn it you can’t unlearn it.

Jam, after stating that she makes her students in introductory geology do Excel exercises, said, 
I want my students to be quantitatively literate.

Sunshine mentioned working unit conversions and other aspects of QL into her courses in introductory geology.

I ask questions at the end of the lecture. Along the lines of quantitative literacy.

Unit conversions were mentioned specifically by Luke, Sam, Sunshine, Gilda, and John Doe. Sunshine mentioned them explicitly in the context of the QL questions she asked in her classes,

I do your stereotypical assignment of unit conversions.

Sam's primary response to the question gave an intrinsically fundamental geological point of view:

One thing that I definitely do on a regular basis is convert from elevation, height above sea level or something, to feet below land surface.

Gilda added unit conversions as the second item she used frequently (after Excel), saying,

And unit conversions, that probably helped a lot too.

John Doe mentioned unit conversions in connection to proportions,

I'd say that proportions I use a lot, and on the other end of that is unit conversions.

The topic of unit conversions came up in answer to more than one question in Luke's interview, with him saying in response to this question,

I hate to keep going back to unit conversions, but that's definitely something that was really stuck in my mind, to make sure you do them right.

John Smith, Lee, Arya, and Medusa, discussed using statistics, or at least statistical literacy, in their professional or personal lives. John Smith asked,

Are you introducing statistical error by setting up a certain way?

Lee said,

I use the statistics that he went over all the time.

Arya completed an MS thesis that used computers to perform detailed statistical analyses on beach sands. In discussing how the computational course had given her a foundation for this work, she said,

I felt like it gave me a little bit more of a starting point because I was not very strong in statistics, so with not having a strong statistical background and doing a thesis that's just highly related to statistics was very stressful but I was able to go back and use my notes to help me along with just doing the basic mathematics that were needed for that.

Medusa had a particularly interesting and personal way of expressing the relevance of the subject to her, 
I don't seem to express myself or learn in ways that fit, you know, that are within one standard deviation of the mean.

She went on to express how she explained to her son his differences and exceptional abilities in terms of standard deviations and the population mean, and said,

And having been through a course like Len's allowed me to see the concept so simply, instead of it being this weird calculation that I'd have to work really hard to be able to function with. It's a very basic concept to me, and it's now a very basic concept that my son uses every day to perceive himself. That's a big deal.

What interviewees mentioned was useful from the course, 2: Individual Perspectives. This section refers to comments made by individuals that were not repeated by other interviewees, or which were so uniquely phrased as to place the response in its own category.

Sam directly linked the course to her ability to maintain personal finances using Excel.

I have spreadsheets of how things are moving and where money is going and all kinds of things like that, and I probably would not know how to do a lot of that stuff if it had not been for that class.

Gilda, like many of the interviewees, took both the computational geology course and the similar graduate course titled Math Concepts for Professional Geologists. She related one use that was relevant in her life that she learned in both courses (part of Polya's first step).

If there's ever any sort of question, I've gotten used to drawing a picture and labeling everything in order to better understand what to do to solve it.

John Doe said something regarding how the course changed the students' thought processes about some terms that reflected a clear habit of mind consistent with QL.

I think what the course did was make us wary of statements like "greater than" or "percent more." Dr. Vacher has a very strict policy on using certain phrases to describe something, so description of percent more should mean percent more than and that was actually a small segment of his course, so I think what it made us, what it makes me do is when someone says something like that or a statistical phrase, I think about it and say, "is that what they really mean,” because I know mistakes are made all the time.

Arya served as an unofficial course TA and used her knowledge of course modules to help write introductory text documents for students that were intended to assist them in getting through unfamiliar terms or processes. "So I would just, I would use my previous, experience to help the students." She also mentioned having used certain math skills from the course in her current occupation as a graduate assistant. "Matrix algebra is a big one and that has helped me I use a lot of vectors.” 
In discussing quantitative literacy in depth, John Smith related QL to his personal life.

It [QL] sort of pervades everything. So it has impacted my personal life, for the better, of course, but things like that. I'll go into the store, I'm trying to get a deal on lemons I'll go, what's the price per ounce here? Should I get the big lemons or the small lemons; get the bag of lemons or should I buy them individually? And the wheels start turning automatically now, whereas I used to just, oh, $\$ 2$, \$1, I'll get the $\$ 1$ bag? But stuff like that happens all the time. I've become a more analytical person because of it.

Lee is in graduate school studying oceanography, and

I manage a large data set. I try to apply numbers to things that I'm doing every day.

When discussing specific skills she uses frequently from the computational course, she stated

I use percent differences and the statistics that he went over, Excel formulas and arrangements all the time.

She suggested that a significant purpose of the computational geology course was to help

not be overwhelmed by the numbers.

Although the use of Excel itself was by no means unique to her, Sunshine had a couple of good stories on how she put Excel to good use. The first was to convince her husband to buy a car:

Well, ever since that course, I have used Excel. I never really used Excel before it, and I love Excel now. I use it for everything. I used it for my chemical data that I collected for my rocks for my master's. I used it to create my budget for my house for my husband. I used an Excel spreadsheet to show my husband that we needed to trade in our other car and buy a new car because it was going to be gas efficient and we were going to save money. And when I did the Excel spreadsheet for convincing my husband to buy a car, I made the spreadsheet up and I had the amount of what gas would cost as a variable, the amount of miles he was traveling, what miles per gallon for each car we were thinking about buying. Then comparing that to what we were spending right now with the car that he was driving, so looking at gas and tolls and then comparing that to how much it would cost, how much it would save us if we bought a new car that was gas efficient, but we had a car payment, but the car payment was still, the car payment plus the gas was still lower than having a car that was already paid off but horrible gas mileage. And I made a whole spreadsheet that he manipulated and played with all these different variables and it changed the bottom number to figure out how much we would save every month. And that convinced him, and we went and bought a new car.

The second was to explain to a student how to pass her course.

Last week I made an Excel spreadsheet for one of my students who was going to fail. And I created an Excel spreadsheet of the labs she has turned in, the quizzes she has turned in, and I color coded the cells for the ones that she could manipulate to see what she would need to get on the labs and the quizzes to get the grade she wanted at the bottom. So at the bottom I had her weighted grade calculated so it would change 
whenever she changed those cells. And that's all stuff that I learned from computational geology.

Sunshine additionally spent time in graduate school employed by HLV organizing the modules over summers, and later wrote a module which is on the Science Education Research Center ${ }^{14}$ (SERC) website. She uses the modules in her current teaching assignment to help students learn QL in geology.

Medusa, the interviewee with the longest perspective, had the following to say about how she has used what she learned in the course.

M: Almost all of it. Um, now I can’t say I that I actively...

VR: Can you elaborate on that?

M: Sorry, I don’t know that I actively, I mean, I don't actively do these calculations any longer. I, you know, I don’t actively write out these equations, however, the work I do...

VR: Now why would that be?

M: Um...

VR: Is it because of the computer does it, or because you're above the level in the company?

M: Several reasons. Both. Now I'm not the person who does the technical aspects as much anymore; I'm more of a project manager, and person who does design for projects. So when I need calculations run, I have folks that do that. And of course we have models that we run; however, I make folks go back and show me that they can do the calculations if they're going to be running the model. One of the strongest things that we learned from this course was that you can make a model do anything. And things have to be able to pass the smell test. It has to make sense. It has to be valid. You can make a model do anything based on the inputs but unless the math is solid, the calculations are solid, the model is meaningless. Again, so what and who cares? Why did I run this model? I would say I use the information that I learned in his class to vet the validity of models that I see every day. I did that as a regulator, and I do that now.

\section{Subjectivity and reflexivity}

It is appropriate in qualitative research to pause and consider "What is the researchers' impact on the research process, what kind of stimulus do they constitute for research participants, which interactions take place between the researcher and the research participants, and what is their outcome?” (Mruck and Breyer 2003). It is certainly true that this case study is anything but objective, particularly in the fact that one of the course instructor's current graduate students is the principal investigator of the qualitative research, and the instructor was so much in the background as a part of the contextual setting (even to the extent that most of the interviews were in the principal investigator's office, which is the instructor's lab).

\footnotetext{
${ }^{14}$ The Science Education Resource Center, housed at Carleton College, http://serc.carleton.edu/index.html
} 
The study is strongly biased on account of the study population. On the other hand, the study was not intended to be representative of the general population of students who took this course over the twenty years of its existence. This lack of random selection constitutes a selection bias. The use of a selection-biased population allows future studies-including possible surveys to representative alumni populations - to feature well-researched questions based on the experiences of the selected, professionally successful interviewees in this study.

Additionally,

- Professional success was entirely in the opinion of the course instructor, and was not based on rigorous testing of any sort.

- Convenience sampling was used due to lack of funds (9 of 10 interviewees were local at the time of the interview).

- Confirmation bias was noted in some follow-up questions (phrasing of questions that shaped possible answers in a specific way). Where noted, these responses were not used for quotations in the text.

Lastly, all interviewees (as well as the interviewer and first author of this paper) were currently or formerly connected to the course instructor (the second author) through letters of recommendation, post-graduate work, or alumni activities. Unsurprisingly, a significant proportion of interviewees felt they owed some debt of gratitude for their position in their career to the course instructor for his teaching, assistance, and guidance in and out of the classroom. (Some expressed this feeling on record, while others have discussed it informally). Although this study is not about any one person, it must be acknowledged that there is an inherent reciprocity in the selection bias mentioned above in that these interviewees are highly unlikely-even given anonymity-to say anything particularly critical of the instructor or the Computational Geology course. This lack of criticism should not be taken as evidence that negative views don't exist; in fact, the second author knows that they do.

\section{So What?}

It is gratifying to see that Medusa remembers the "so what?" question. If indeed she did get it from her Computational Geology course nearly 20 years ago, it is worth passing on again the ultimate source: a widely shared editorial for students from a renowned researcher of reefs in Florida and on Earth (Ginsburg 1982, 351),

“'So what?" stands for a family of questions or an attitude that leads to consideration of the broader significance of specific studies. These kinds of questions are particularly useful in descriptive research because, often, one can get so absorbed in collecting, organizing and analyzing observations one forgets to consider the implications of the results. 
The "So What?" of our descriptive case study follows from its three-pronged setting:

1. It occurs within a time in which institutions, programs, and courses in higher education seek to distinguish between outputs (productivity) and outcomes (what students take away) (e.g., Dugan and Hernon 2002). For our GLY course, the intended take away, clearly and emphatically, is QL.

2. The Association of American Colleges and Universities specifically lists QL (along with information literacy, problem solving, critical thinking, creative thinking, ethical reasoning, and global learning, among others) as essential learning outcomes (AAU\&U 2007; see also Vacher 2011).

3. Madison's question (Madison 2001) still resonates: Who in the academy has responsibility for QL? Our answer to Madison's question is that the disciplines share in the responsibility. QL as a learning outcome is not solely the mathematicians' responsibility. That belief energizes our course, and it motivates this paper.

Broadly within the discipline of geology, there appear to be three approaches to building the QL of our students:

1. 'Integrat(ing) quantitative tasks into courses to illuminate students' understanding of geoscience, as well as to enhance their quantitative skills" (Macdonald et al. 2000, as quoted in our Introduction). (For Numeracy papers, see also Wenner et al. 2009, Lehto and Vacher 2012, and Wenner and Baer 2015).

2. Requiring majors to take geology electives that stretch them mathematically while sharpening their problem-solving skills (as in the "quantitative requirement" in GLY at USF noted in the background section; see also Connor and Vacher 2016).

3. Offering a course within the discipline in which QL coupled with problem solving experiences is the framework and substance, while the geology provides supporting and motivating material.

Clearly, the Computational Geology course of this paper is an example of the third approach. As far as we know, it is the only example. Therefore, it is incumbent on us to ask from the alumni interviews: What values can we say that these alumni of Computational Geology took away from the experience?

On the notion of values, we draw on a study by Norris et al. (2014) of a kindred literacy as an educational goal. In that study, a Google Scholar ${ }^{\mathrm{TM}}$ search using "scientific literacy” produced 62 articles published since 2000 that either classified or justified the objectives of scientific literacy. According to those researchers (Norris et al. 2014, 1320),

... we find it valuable to categorize the proposed outcomes of scientific literacy into three categories of values: values regarding the states of knowing one might obtain, values regarding the capacities one might refine, and values regarding the personal traits one might develop. We call them all values because they refer to ends of science education that are judged desirable. 
With a framework, then, of (1) states of knowing, (2) capacities, and (3) traits (Norris et al. 2014) as a guide, we can list some of the takeaways that some of the interviewees expressed - in their own words:

1. States of knowing one might develop, such as understanding and knowledge (e.g., facts and concepts)

- Facts: Conversion factors

He's not telling you the conversion factor between one thing and another... that's your responsibility to know. And that's something that really carries through into the professional world. - John Smith

- Facts: Excel functions

I think I have probably used every single Excel function that Dr. Vacher showed us. - Gilda

- Facts: Orders of operation

You have to know the order to do the calculations in or else you're going to be wrong - Arya

- Concepts: Percentage

What the course did was make us wary of statements like greater than or percent more. - John Doe

- Concepts: Logs

...the log scales ...I really remember a lot, because that stuff I have trouble with...-- Arya

- Concepts: Logic as a process

That was his entire course, was just learning how to think through things logically in a step by step manner. - Lee

- Concepts: Calculus is geological

A derivative is change over time, that's all it is. Geology is change over time. Almost everything we look at in geology is change over time. - Medusa

2. Capacities one might refine, such as abilities (skills)

- Communication:

If you could sit in an airplane next to somebody and explain a math problem on a... cocktail napkin, and you could draw a little diagram, you were successful in his class. - Sunshine

- Excel

I learned a lot about Excel... I can look through a sheet and reverse engineer it, find out the calculations... that people have submitted to me. - Luke

- Unit conversions

Converting, you know, from different units and that sort of thing. - Sam

3. Traits one might develop, such as dispositions

- Problem solving

The relevance for my everyday job would probably be using the same problem solving skills that we learned... I'm never going to have to try to solve the same exact problems he presented, but I can use the same steps that he showed us in order to solve whatever I might run into. - Gilda 
That class really instilled in me a sense of...thoroughness....There's always something lurking in the shadows that you need to address...when a problem comes up. - John Smith

- Confidence

He made it a tool I can use, and made it something I wasn't afraid to use, and made it something I was excited to use and felt empowered by instead of somewhat fearful of. - Medusa

- Analytical thought

I've become a more analytical person because of it. - John Smith

- Quantitative literacy

I want my students to be quantitatively literate. - Jam

Returning to the "So What?" of Ginsburg (1982), then, we can state the broader implication of our specific study: We have an example here ("an existence proof,” as Madison might call it) of a long-standing and still-cranking, standalone QL course for upper-division, in-discipline majors in a STEM discipline. Thus QL can be developed-and indeed welcomed in the home discipline-in a course not taught by mathematicians.

It is important to underscore an additional observation. The QL takeaways of our interviewees are basically the same from the era of Medusa (in 1997) and Jam (2001), when the evolving Computational Geology was in its more mathematical literacy stage, to John Smith (2011), John Doe (2012) and Lee (2013), when the evolution had taken the course unabashedly into the domain of traditional QL. The common element throughout the story was problem solving. In other words, the type and level of the mathematics didn't matter. It is the context that makes the course go and gives it legitimacy for the people it serves.

\section{Concluding Remark}

Returning to Madison and "Everybody’s Orphan," it would be unfortunate if the need to pitch in and adopt the orphan would be seen as a burden. After our experiences teaching Computational Geology (2 years and 20 years, respectively), we can attest that the subject is a pleasure to teach. Probably the biggest reason is that we are at home with the context, which gives us common ground with our students. A second reason is that an amazing proportion of our students have had bad experiences in prior math encounters. To the extent that we can use their positive attitude about geology to discover their mathematical selves by recognizing the beneficence of mathematics as a way of doing things that matter to them ("a tool I can use," said Medusa, perhaps quoting the textbook she used in the course, Waltham 1994), and they find that now this math stuff does make sense after all— teaching QL in the discipline thus becomes its own reward. 


\section{Acknowledgments}

The qualitative research reported here was part of VJR's MS thesis (Ricchezza 2016), and we thank Jeff Raker and Jeff Ryan for their guidance as proactive members of the thesis committee. We thank the three Numeracy reviewers for their helpful comments, all of which led to substantial sharpening and clarification. HLV thanks the successive departmental chairs (Mark Stewart, Chuck Connor, Jeff Ryan, and Mark Rains) for their support of the course and their belief in the value of QL for geology majors. Finally, words cannot express our gratitude to the more than 300 students for their forbearance and the ten interviewees for their generous contributions to our study.

\section{References}

\section{Part A. Papers}

Association of American Colleges \& Universities. 2007. "College Learning for the New Global Century. A Report from the National Leadership Council for Liberal Education \& America's Promise.” Accessed Sept 23, 2016. https://www.aacu.org/sites/default/files/files/LEAP/GlobalCentury_final.pdf Accessed Sept 23, 2016. http://aacu.org/leap/essential-learning-outcomes.

Anderson, Janet, and Todd Swanson. 2005. Understanding Our Quantitative World. Washington, D.C.: Mathematical Association of America.

Connor, C. B., and H. L. Vacher. (2016) "Learning Volcanology: Modules to Facilitate Problem Solving by Undergraduate Volcanology Students.” Statistics in Volcanology 2: Article 3. http://dx.doi.org/10.5038/2163-338X.2.3

Derringh, Edward. 1998. Computational Engineering Geology. Prentice Hall.

Devlin, Keith. 2000. "The Four Faces of Mathematics.” In Learning Mathematics for a New Century. 2000 Yearbook, edited by M. J. Burke and F. R. Curcio, 16-27. Reston, VA: National Council of Teachers of Mathematics.

Dugan, Robert E, and Peter Hernon. 2002. "Outcomes Assessment: Not Synonymous with Inputs and Outputs.” The Journal of Academic Librarianship 28 (6): 376-380. https://doi.org/10.1016/S0099-1333(02)00339-7.

Fratesi, Sarah E., and H.L. Vacher. 2005. "Using Spreadsheets in Geoscience Education: Survey and Annotated Bibliography of Articles in the Journal of Geoscience Education through 2003." Spreadsheets in Education 1 (3): 190-216. Accessed June 22, 2010. http://epublications.bond.edu.au/ejsie/vol1/iss3/3.

Gaze, Eric. 2014. "Teaching Quantitative Reasoning: A Better Context for Algebra.” Numeracy 7 (1): Article 1. http://dx.doi.org/10.5038/1936-4660.7.1.1

Ginsburg, R.N. 1982. "Editorial. Seeking Answers: Suggestions for Students.” Journal of Sedimentary Petrology 52 (2): 351-352. https://doi.org/10.2110/jsr.52.351.

Glaser, Barney G. 1965. “The Constant Comparative Method of Qualitative Analysis.” Social Problems: 436-445. https://doi.org/10.2307/798843.

Grawe, N.D., and H. L. Vacher. 2017. "A Madison-Numeracy Citation Index (2008-2015): Implementing a Vision for a Quantitatively Literate World.” Numeracy 10 (1): Article 1.

Karaali, Gizem, Edwin H. Villafane Hernandez, and Jeremy Taylor. 2016. "What's in a Name? A Critical Review of Definitions of Quantitative Literacy, Numeracy, and Quantitative Reasoning.” Numeracy 9 (1): Article 2. http://dx.doi.org/10.5038/1936-4660.9.1.2. 
Lehto, Heather L., and H.L. Vacher. (2012) "Spreadsheets Across the Curriculum, 4: Evidence of Student Learning and Attitudes about Spreadsheets in a Physical Geology Course.” Numeracy 5 (2): Article 5. http://dx.doi.org/10.5038/1936-4660.5.2.5

Lutz, T. M., and LeeAnn Srogi. 2000. "The Role of a Shadow Course in Improving the Mathematics Skills of Geoscience Majors.” Journal of Geoscience Education 48 (4): 474478. https://doi.org/10.5408/1089-9995-48.4.474.

Macdonald, R. Heather, LeeAnn Srogi, and Glen Stracher, eds. 2000a. Special Issue: Building the Quantitative Skills of Students in Geoscience Courses. Journal of Geoscience Education 48 (4). National Association of Geoscience Teachers. http://nagt.org/nagt/jge/abstracts/sept_2000.html

. 2000b. "Building the Quantitative Skills of Students in Geoscience Courses.” Journal of Geoscience Education 48 (4): 409-412. http://dx.doi.org/10.5408/1089-9995-48.4.409

Madison, Bernard L. 2001. “Quantitative Literacy: Everybody’s Orphan.” Focus 21 (6): 10-11.

— , and Lynn Arthur Steen. 2008. "Evolution of Numeracy and the National Numeracy Network.” Numeracy 1 (1): Article 2. http://dx.doi.org/10.5038/1936-4660.1.1.2.

McGee, Dorien K. 2010. "Learning Quantitatively: Assessing the Role of Spreadsheets Across the Curriculum.” In Microbial Influences on Karst Dissolution: The Geochemical Perspective, with a Chapter on Assessment of the Spreadsheets Across the Curriculum Project. Ph.D. dissertation, University of South Florida. Graduate Theses and Dissertations. http://scholarcommons.usf.edu/etd/3632.

Mruck, K., and F. Breuer, 2003. "Subjectivity and Reflexivity in Qualitative Research - the FQS Issues.” FQS Forum: Qualitative Social Research Sozialforschung 4 (2): Article 23. May 2003. https://doi.org/10.1007/978-94-007-7654-8_40.

Nocita, B., C. Connor, G. S. Herbert, M. Rains, E. Rodriguez, J. Ryan, and H. L. Vacher. 2016. "How a Geology Alumni Society and Professional Community Contribute to the Preparation of Graduate Students for a Geoscience Career at the University of South Florida (Abs.).” Geological Society of America Abstracts with Programs. Vol. 48, No. 7, Paper 298-3.

Norris, Stephen P, Linda M. Phillips, and David P. Burns. 2014. "Conceptions of Scientific Literacy: Identifying and Evaluating Their Programmatic Elements. Chapter 40.” International Handbook of Research in History, Philosophy and Science Teaching, ed. M. R. Matthews. Dordrecht: Springer. http://doi.org/10.1007/978-94-007-7654-8_40.

Patton, Michael Quinn. 2015. Qualitative Evaluation and Research Methods. 4th ed. Thousand Oaks, CA: Sage Publications, Inc.

Pólya, George. 1957. How to Solve It. 2nd ed. Garden City, NY: Doubleday.

Rhodes, Terrel. 2010. "Assessing Outcomes and Improving Achievement: Tips and Tools for Using Rubrics.” Association of American Colleges \& Universities.

Ricchezza, Victor J. 2016. "Alumni Narratives on Computational Geology (Spring 1997 - Fall 2013).” Graduate Theses and Dissertations. http://scholarcommons.usf.edu/etd/6366

_ and H. L. Vacher. 2016. "On a Desert Island with Unit Sticks, Continued Fractions and Lagrange.” Numeracy 9 (2): Article 8.

Rodriguez, E., R.E. Bretnall, D.J. DeWitt, and H. L. Vacher. 2002. "The Alumni Network: Forging Connections Between the Usf Geology Department and the Professional Community (Abs.).” GSA Annual Meeting \& Exposition Denver Annual Meeting.

Roohr, K. C., E. A. Graf, and O. L. Liu. "Assessing Quantitative Literacy in Higher Education: An Overview of Existing Research and Assessments with Recommendations for NextGeneration Assessment.” Research Report ETS RR-14-22. Princeton, NJ: Educational Testing Service. https://doi.org/10.1002/ets2.12024.

Sons, Linda, ed. 1996. Quantitative Reasoning for College Graduates: A Complement to the Standards. Washington, D.C.: Mathematical Association of America. 
Steen, Lynn Arthur. 1997. Why Numbers Count: Quantitative Literacy for Tomorrow's America. New York, NY: College Entrance Examination Board.

. 2001. Mathematics and Democracy. National Council on Education and the Disciplines.

Strauss, Anselm, and Juliet Corbin. 1994. "Grounded Theory Methodology.” Handbook of qualitative research: $273-285$

Sweller, John, Paul Ayers, and Slava Kalyuga. 2011. Cognitive Load Theory. New York: Springer-Verlag. https://doi.org/10.1007/978-1-4419-8126-4.

Vacher, H. L. 2000a. "A Course in Geological -Mathematical Problem Solving.” Journal of Geoscience Education 48 (4): 478-481. https://doi.org/10.5408/1089-9995-48.4.478.

_. 2000b. "Computational Geology 13 - Geological-Mathematical Activities for College Students in the Journal of Geoscience Education, 1990-1999.” Journal of Geoloscience Education 48 (5): 682-691. https://doi.org/10.5408/1089-9995-48.5.682.

—. 2011. "A LEAP Forward for Quantitative Literacy.” Numeracy 4 (2): Article 1. http://doi.org/10.5038/1936-4660.4.2.1.

. 2014. "Looking at the Multiple Meanings of Numeracy, Quantitative Literacy, and Quantitative Reasoning.” Numeracy 7 (2): Article 1. http://doi.org/10.5038/1936-4660.7.2.1.

— . 2016. "Remembering Lynn Steen: A Steen-Numeracy Citation Index (2008-2015)." Numeracy 9 (1): Article 1. http://dx.doi.org/10.5038/1936-4660.9.1.1.

— Resource.” Numeracy 3 (2): Article 6. http://doi.org/10.5038/1936-4660.3.2.6.

Vacher, H.L., Thomas Juster, Judy McIlrath, and Mark Rains. 2012. "Geology of National Parks Modules for the Spreadsheets Across the Curriculum Library.” In Weber, Samantha, ed. 2012. Rethinking Protected Areas in a Changing World: Proceedings of the 2011 GWS Biennial Conference on Parks, Protected Areas, and Cultural Sites. Hancock, Michigan: The George Wright Society. http://www.georgewright.org/proceedings2011

Vacher, H. L. 2005. “Computational Geology Series (1998-2005).” National Association of Geoscience Teachers.

— C.B. Connor, and V. Ricchezza. 2016. "Word Problems: Living at the Intersection of Quantitative Literacy and Geological-mathematical Problem Solving.” (Demonstration and posted PowerPoint by VR). Earth Educators Rendezvous, Madison WI., July 18-22.

Waltham, D. 1994. Mathematics: A Simple Tool for Geologists. London: Routledge.

Wenner, Jennifer M. and Baer, Eric M. D. (2015) "The Math You Need, When You Need It (TMYN): Leveling the Playing Field.” Numeracy 8 (2): Article 5. http://doi.org/10.5038/1936-4660.8.2.5

_- Cathryn A. Manduca, R. Heather Macdonald, Samuel Patterson, and Mary Savina. 2009. "The Case for Infusing Quantitative Literacy into Introductory Geoscience Courses." Numeracy 2 (1): Article 4. http://dx.doi.org/10.5038/1936-4660.2.1.4.

\section{Part B. Spreadsheet modules}

Baer, Eric M. D. 2006. "Shaking Ground - Linking Earthquake Magnitude and Intensity.” Olympia, WA: The Washington Center for Improving the Quality of Undergraduate Education. http://serc.carleton.edu/sp/ssac_home/general/examples/eqshake.html

Butler, Paul. 2006. "Global Climate: Estimating How Much Sea Level Changes When Continental Ice Sheets Form.” Olympia, WA: The Washington Center for Improving the Quality of Undergraduate Education. http://serc.carleton.edu/sp/ssac home/general/examples/14356.html

Cole, Robert. 2006. "Carbon Sequestration in Campus Trees.” Olympia, WA: The Washington Center for Improving the Quality of Undergraduate Education. http://serc.carleton.edu/sp/ssac home/general/examples/14323.html 
Coolidge, Cheryl. 2006. "Is It Hot in Here? - Spreadsheeting Conversions in the English and Metric Systems.” Olympia, WA: The Washington Center for Improving the Quality of Undergraduate Education. http://serc.carleton.edu/sp/ssac_home/general/examples/14348.html

Herbelin, Armando. 2007. "Buffer Capacity in Chemical Equilibrium: How Long Can You Hyperventilate Before Severe Alkalosis Sets In?” Olympia, WA: The Washington Center for Improving the Quality of Undergraduate Education. http://serc.carleton.edu/sp/ssac_home/general/examples/19140.html

Juster, Thomas C. 2010. “A Percentage Stroll Through Norris Geyser Basin, Yellowstone National Park.” Tampa, FL: University of South Florida Libraries. (Cover page by Len Vacher and Denise Davis.) http://serc.carleton.edu/sp/ssac/national_parks/examples/norris geyser.html

. 2011. "How Faithful Is Old Faithful? Finding Order in Random Behavior.” Tampa, FL: University of South Florida Libraries. (Cover page by Len Vacher and Denise Davis.) http://serc.carleton.edu/sp/ssac/national_parks/examples/34200.html

Lehto, Heather. 2009. "How Much Water Is in Crater Lake? Using Prisms to Calculate Volume.” Tampa, FL: University of South Florida Libraries. http://serc.carleton.edu/sp/ssac/national_parks/examples/crater_lake_volume.html

Dorien McGee. 2006. "Radioactive Decay and Popping Popcorn - Understanding the Rate Law.” http://serc.carleton.edu/sp/ssac_home/general/examples/14332.html.

McGee, Dorien, Meghan Lindsey, and H. L. Vacher. 2009. "Spreadsheet Warm up for SSAC Geology of National Parks Modules.” Tampa, FL: University of South Florida Libraries. (Cover page by Len Vacher.) http://serc.carleton.edu/sp/ssac/national_parks/examples/gnp_warmup.html - 2011. "Spreadsheet Warm up for SSAC Geology of National Parks Modules, 2: Elementary Manipulations Ad Graphing Tasks.” Tampa, FL: University of South Florida Libraries. (Cover page by Len Vacher and Denise Davis.) http://serc.carleton.edu/sp/ssac/national_parks/examples/warmup_2.html

Rains, Mark C., H. L. Vacher, and Marian Norris. 2011. "Nitrate Levels in the Rock Creek Park Watershed, Washington D.C., 1: Measures of Central Tendency.” Tampa, FL: University of South Florida Libraries. (Cover page by Len Vacher and Denise Davis.) http://serc.carleton.edu/sp/ssac/national_parks/examples/ROCR1.html

Roberts, Tiffany M. 2010. "Dunes, Boxcars, and Ball Jars: Mining the Great Lakes Shores.” Tampa, FL: University of South Florida Libraries. (Cover page by Len Vacher and Denise Davis.) http://serc.carleton.edu/sp/ssac/national_parks/examples/great_lakes_mining.html

Stringer, Christina. 2005. "Radioactive Decay and Popping Popcorn - Understanding the Rate Law.” Olympia, WA: The Washington Center for Improving the Quality of Undergraduate Education. http://serc.carleton.edu/sp/ssac_home/general/examples/decay.html

Thomas, Bill. 2005. “Calibrating a Pipettor.” Olympia, WA: The Washington Center for Improving the Quality of Undergraduate Education. http://serc.carleton.edu/sp/ssac home/general/examples/15970.html

Vacher, Len. 2005a. "How Large Is a Ton of Rock? - Thinking about Rock Density.” Olympia, WA: The Washington Center for Improving the Quality of Undergraduate Education. http://serc.carleton.edu/sp/ssac_home/general/examples/14439.html

. 2005b. "How Far Is Yonder Mountain? - A Trig Problem.” Olympia, WA: The Washington Center for Improving the Quality of Undergraduate Education. http://serc.carleton.edu/sp/ssac_home/general/examples/14440.html

_. 2006a. "Frequency of Large Earthquakes - Introducing Some Elementary Statistical Descriptors.” Olympia, WA: The Washington Center for Improving the Quality of 
Undergraduate Education.

http://serc.carleton.edu/sp/ssac home/general/examples/15653.html

. 2006b. "How Large Is the Great Pyramid of Giza? - Would It Make a Wall That Would Enclose France?” Olympia, WA: The Washington Center for Improving the Quality of Undergraduate Education.

http://serc.carleton.edu/sp/ssac_home/general/examples/14935.html

_ 2006c. "Earth's Planetary Density - Constraining What We Think of the Earth's Interior." Olympia, WA: The Washington Center for Improving the Quality of Undergraduate Education. http://serc.carleton.edu/sp/ssac_home/general/examples/15087.html -, and Susan Sachs. 2011. "Take a Deep Breath on the Appalachian Trail in Great Smoky National Park: How Many Molecules of Ozone Do You Inhale?” Tampa, FL: University of South Florida Libraries. (Cover page by Len Vacher and Amie Fishinger) http://serc.carleton.edu/sp/ssac/national_parks/examples/35175.html

Vacher, Len, Mark C. Rains, and Marian Norris. 2011. "Nitrate Levels in the Roc Creek Park Watershed, Washington D.C., 2: Variability.” Tampa, FL: University of South Florida Libraries. (Cover page by Len Vacher and Denise Davis.) http://serc.carleton.edu/sp/ssac/national_parks/examples/ROCR2.html

Vacher, Len, Jim Renfro, and Susan Sachs. 2011. "Deciviews from Look Rock, Great Smoky Mountains National Park: How Hazy Is It?” Tampa, FL: University of South Florida Libraries. (Cover page by Len Vacher and Amie Fishinger.) http://serc.carleton.edu/sp/ssac/national_parks/examples/34447.html

Wetzel, Laura. 2005. "Earthquake Magnitude: How Can We Compare the Sizes of Earthquakes?” Olympia, WA: The Washington Center for Improving the Quality of Undergraduate Education. http://serc.carleton.edu/sp/ssac home/general/examples/14337.html 